\title{
LA SOCIALIDAD LÚDICA JUVENIL. SOBRE CÓMO LOS JÓVENES EROSIONAN EL ORDEN SOCIOCULTURAL INSTITUIDO CUANDO SE DIVIERTEN ${ }^{1}$
}

\author{
J. Ángel Bergua
}

Universidad de Zaragoza

\begin{abstract}
RESUMEN
La juventud no debe ser definida por las carencias que padece frente a los adultos, derivadas de su posición subordinada en instituciones centrales de la sociedad tales como el trabajo y la familia. Al contrario, es necesario descubrir la diferencia cultural de la que es portadora prestando atención a las singulares prácticas sociales que protagoniza. Partiendo de esta idea y siguiendo a Caillois, se comparan los ceremoniales agon (relaciones interpersonales, entre los géneros y con los objetos), ilinx (autoalteración de la conciencia mediante la ingestión de drogas) y mimicry (usos y funciones simbólicas otorgadas al vestuario), además de la apropiación del espacio y de los gustos musicales, de los públicos juvenil y adulto de la discoteca But y de la sala de fiestas Pasapoga, ambas en Madrid. La conclusión es que mientras los adultos permiten que se sostengan ciertos pilares socioculturales emblemáticos de la modernidad, los jóvenes tienden inercial y espontáneamente a erosionar su dominio.
\end{abstract}

\section{INTRODUCCIÓN}

La sociología suele definir a la juventud como el colectivo de cierta edad que todavía no ha adquirido la condición de adulto y entiende que el ingreso

${ }^{1}$ Este artículo es el resumen de una parte de la tesis que defendí en la Facultad de Ciencias Políticas y Sociología de Madrid el 23 de febrero de 1996. Su dirección corrió a cargo de Antonio Muñoz Carrión. Además, resultó fundamental el auxilio de Luis Lles para entender la magia y encanto de la technomusic. 
en esta otra clase de edad se da por la asunción de una cuádruple responsabilidad: productiva (asignación de un status ocupacional, laboral o profesional estable), conyugal (asignación de una pareja sexual estable), doméstica (asignación de un domicilio estable y autónomo) y parental (asignación de una prole dependiente) (Garrido, 1980; Gil Calvo, 1985; Gil Calvo y Meléndez Vergara, 1985: 25). A esta definición se añade que el joven no es aún adulto pero que está en condiciones de serlo, pues podría material y formalmente, a diferencia del niño, hacer casi todo lo que un adulto hace en sociedad (Zárraga, 1985: 21).

Sin embargo, también es posible definir a los jóvenes no según las carencias que padezcan frente a los adultos, sino teniendo en cuenta sus singulares y originales prácticas (Galland, 1991; Reguillo, 1991: 22). Partiendo de este otro punto de vista es posible suponer que la capacidad de los jóvenes para diferir del orden en el que están centralmente inscritos los adultos debe aludir a una competencia cultural diferente que les lleva no a desear adquirir las responsabilidades mencionadas, sino a afirmarse a partir de otros estilos de vida. Si se da esta hipótesis por válida es necesario proponer un marco teórico en el que el lugar central que ocupan instituciones como el trabajo y la familia, sobre las que se vuelca la responsabilidad, sea ocupado por instituciones diferentes y opuestas a las anteriores, como son la diversión y la fratria o grupo de iguales (Brown, 1986: 22). Precisamente el objetivo de este artículo es mostrar la alteridad de la que son portadores los jóvenes analizando ciertos rituales lúdicos.

No obstante, como se comprobará, también esta apuesta teórica puede desembocar en una evaluación negativa. La razón es doble. Por un lado, el instrumental teórico necesario para dar cuenta de esa otra sociabilidad juvenil no suele dar la talla debido a estar en gran medida producido para analizar la vertiente oficial de la sociedad, la que hegemonizan el trabajo, la familia y otras instituciones consideradas centrales. Por otro lado, los mismos jóvenes se ven obligados a ocultar o a reprimir la disidencia que quieren pero no pueden manifestar debido a la presión cultural e ideológica que sobre ellos ejerce el orden oficial. En realidad, no son dos razones distintas sino una sola, pues el mismo orden que en la práctica reprime de hecho la disidencia juvenil, en el plano teórico bloquea de derecho su análisis. Y es que la ciencia es la prolongación teórica de un dispositivo de dominación ideológico que, en este caso, ejerce la edad adulta sobre la juvenil para hacer valer cierto orden ${ }^{2}$. Con el

2 No es exagerada la afirmación. Según Sáez Martín (1995: 166-167), el Instituto de la Juventud se crea en 1961 ante la «ola de desórdenes juveniles» iniciada unos años antes con la intención no sólo de saber cómo son los jóvenes, sino también y sobre todo cómo hay que tratarlos. En Estados unidos (Passerini, 1996: 419 y ss.), el término teenager se utilizó por primera vez en 1941 para codificar cierto grupo de edad (entre 13 y 19 años) que rápidamente se inscribió en un campo semántico próximo a la criminalidad y que justificó la creación en los cincuenta y comienzos de los sesenta de distintas instituciones tutelares. Pero lo joven no sólo despierta miedo entre los adultos y sus instituciones, sino también atracción y esperanza. De modo que no es arriesgado concluir que la sociedad se construye y proyecta a partir de la ambivalente imagen que se hace de los jóvenes (Espín Martín, 1986; Lozano i Soler, 1994: 41-49). 
mismo problema se encuentran las investigaciones que pretenden investigar otras alteridades sociales ${ }^{3}$.

Para construir un modelo alternativo hay que partir del reconocimiento de que lo social engloba dos vertientes distintas. Por un lado, el Estado, esa instancia trascendida de la vida comunitaria, tutela sociabilidades elaboradas, garantiza la centralidad de ciertas instituciones (como la familia y el trabajo) y, en general, ampara a la sociedad instituida. Por otro lado, lo popular conjura permanentemente el orden anterior dando cobijo a sociabilidades primarias lúdicas o fratriarcales que producirán socialidades instituyentes ${ }^{4}$. Este enunciado teórico afirma bastantes cosas que requerirían ser extensamente justificadas. Sin embargo, sólo me detendré en la aclaración de dos. En primer lugar, en el hecho de que la gente logra bloquear desde abajo la heteronomía o control exógeno que desde arriba intenta imponer o tutelar el Estado. Y, en segundo lugar, en qué consiste exactamente el carácter primario o elaborado de las sociabilidades.

\subsection{La gente contra la sociedad}

Respecto al primer asunto, algunos antropólogos (Clastres, 1974, 1981) ya han observado que las sociedades sin Estado disponen de ciertos mecanismos que les permiten bloquear la aparición o exteriorización de la relación dominantes/dominados, básica en las sociedades centradas en torno al Estado. También en la Edad Media europea, a pesar de que lo social estaba ya estable e irreversiblemente escindido en dominantes y dominados, estos últimos parecen haber disfrutado de una gran autonomía cultural debido a que las élites impusieron un orden muy exigente política y económicamente pero que aún permitía a las gentes producir y experimentar sin muchas mediaciones su propia cul-

3 En efecto, cierto feminismo diferencialista (Irigaray, 1987) ha denunciado el tener que enfrentarse a dispositivos teóricos y prácticos de dominación, en este caso impuestos por una cultura anclada en la masculinidad, que les impide manifestar y analizar la alteridad de la que las mujeres son portadoras. Algo parecido ha sucedido con las prácticas populares (Grignon y Passeron, 1992) debido a que se ha solido partir de una noción de cultura propia de las élites. Otro ejemplo de alteridad es la cultura oriental. Said (1990) ha mostrado que el Orientalismo es una disciplina científica inventada por Occidente para traducir o eufemizar la alteridad oriental y poner ese conocimiento al servicio de cierta política.

${ }^{4} \mathrm{Al}$ utilizar el término "socialidad" para designar un espacio de interacción distinto al instituido y más primario tengo en cuenta a Maffesoli $(1979,1985,1990,1992)$. En cuanto al término «sociabilidad» (que designa los flujos de interacción más o menos primarios o elaborados) tengo en cuenta a Duvignaud $(1990 a, 1990 b)$. Por otro lado, la referencia de Deleuze y Guattari (1985: 395 y ss.; 1988: 74 y 268-274; 1993: 91-92 y 204-205) a los planos de consistencia (trascendentes) y de inmanencia, así como a los movimientos desterritorializadores y reterritorializadores, creo que es igualmente importante. Por su parte, García Calvo (1989: 391-394) ha hecho referencia al carácter inmanente e inestable del pueblo, así como a su antítesis natural, el Estado. Por último, De Certeau (1993: 205 y ss.) se ha referido de un modo parecido al pueblo pero subrayando la apropiación perversa y subversiva que realiza del orden instituido. 
tura (Gellner, 1994: 24; Bajtin, 1990: 22 y ss.). Es cierto que desde el siglo XVI las élites religiosas, las políticas, los filántropos y los folcloristas desmantelaron esa riquísima vida socialitaria (Burke, 1991: 295 y ss.) y que a principios del siglo XX el pueblo pareció haber sido absorbido del todo en la nueva sociedad moderna (Ortega, 1994: 73-80). Sin embargo, desde los años cuarenta distintas investigaciones y desde distintos flancos han redescubierto la alteridad popular en el centro mismo de la sociedad moderna ${ }^{5}$. De modo que puede ser aceptada la hipótesis de que cierta parte de lo social, la socialidad, tiende a refractar ese orden instituido que se suele designar como sociedad.

Pero ¿qué es exactamente el pueblo o la gente, esa categoría que magnetiza la actividad de la socialidad y que bloquea el plan de ordenación tutelado por el Estado? Para García Calvo, la gente es una "pluralidad indefinida» que refracta espontáneamente tanto el dominio político como el conocimiento científico. Decía Heráclito (García Calvo, 1985: 37 y ss.; 1991a: 134) que, aunque es común a todos la propiedad de razonar, cada uno termina sintiendo que piensa por él mismo y que tiene ideas propias en relación a algo exterior e independiente que llama Realidad. De este modo, la razón se convierte en creencia y cura a cada individuo contra las amenazas de lo desconocido. Pero con ese movimiento trascendente las ideas y los individuos que las portan también se expropian de su razón común, se alienan. Lo mismo sucede con el lenguaje al escindirse en los campos que Bhüler (1985: 98 y ss., 167 y ss.) denominara mostrativo y simbólico, pero que García Calvo prefiere nombrar, respectivamente, "mundo en el que se habla» $\mathrm{y}$ "mundo de que se habla» ${ }^{6}$. Antes del «mundo de que se habla» (o campo simbólico), el de la realidad ideada y creída, está el «mundo en el que se habla» (o campo mostrativo), construido con los deícticos y otras partículas que logran producir sentido pero sin necesidad de referise a ningún significado estable y que son prolongación de los gestos de señalación.

Esta unión tensional entre los dos mundos, que atraviesa de parte a parte a la lengua cuando entra en acción, cuando es hablada, la aclara García Calvo ideando una situación original y singular. Antes de existir nada ni nadie supongamos que, de repente, se inaugura cierto orden de sentido cuando alguien dice algo. En ese mismo instante se despliegan dos campos claramente distintos que después se confundirán: la acción misma de decir realizada por un indefinido alguien y la mención o el algo que resulta dicho. Ambos campos se corresponden, respectivamente, con los mundos en/de que se habla. Más tarde, los campos o mundos se enredarán. Lo que se haya mencionado estará

Es lo que sucede con la lógica de las tribus-masas de Maffesoli (1990: 221), con las apropiaciones imaginarias analizadas por De Certeau (1990: 50-67), con los procedimientos de interpretación-construcción de la realidad estudiados por los etnometodólogos (Cicourel, 1979: 185), o con los mosaicos culturales que nos descubren los Cultural Studies (Grandi, 1995: 93 y ss.; Hall, 1992: 277-294).

${ }^{6}$ Acerca del pueblo y de los mundos en/de que se habla, véase García Calvo (1985: 35-122; 1989: 33-56, 387 y ss.; 1991a: 34-54 y 331-392; 1993: 91-117; 1995). 
«aquí» o "allí» y participará, a través de tales deícticos, de la lógica del campo mostrativo o mundo en que se habla. Por su parte, al alguien le serán adjudicados nombre y cualidades más o menos estables, así que pasará a estar también determinado por el campo simbólico o mundo de que se habla. De modo que ambos espacios, aun siendo distintos, están hibridados. Pero lo que conviene resaltar es que el campo mostrativo o mundo en que se habla, aunque aparece con el gesto lingüístico, es exterior y previo a tal gesto, es pregramatical. Así que siempre resulta imposible acceder a él desde el mundo de que se habla aunque su exterioridad se presienta. Pues bien, este inaccesible mundo en el que se habla cae bajo el dominio del pueblo, o de la gente, mientras que el mundo de que se habla pertenece, o tiende a pertenecer, al Estado, en tanto que fijador simbólico y guardián de la realidad ${ }^{7}$.

Dice también García Calvo que con la gramática de la lengua sucede, tal como demuestra la experiencia del niño desde que contacta por primera vez con ella hasta que se hace hablante completo, que sólo la manejamos bien cuando la olvidamos. Dicho de otro modo, es seguramente necesario en un primer momento de nuestra biografía construir un «saber consciente» acerca de ella, pero también es necesario reprimir ese saber, tornarlo subconsciente, para que se pueda hablar automáticamente, sin necesidad de andar prestando atención en cada paso a la complicada lógica que rige su funcionamiento. Pero, como es obvio, ese subconsciente desde el que la lengua habla no puede ser sólo el personal, pues lo comparte la comunidad de hablantes, así que debe pertenecer a todos ellos, debe ser colectivo. Pues bien, ese subconsciente común y preindividual en el que reside el saber hacer lógico y automático de la lengua es el pueblo, la gente, una pluralidad indefinida (no numérica) de la que no puede decirse mucho - conviene insistir en esto-, sólo sentirla, pues se sustrae al mundo de que se habla o campo simbólico poblado por ideas que es, en último término, desde el que hacemos ciencia ${ }^{8}$.

Se infiere de lo anterior que la investigación lingüística debe realizar una operación inversa a la que tiene lugar con el aprendizaje de la lengua. Consiste en «hacer subir al nivel del saber consciente aquello que ha quedado relegado por necesidades técnicas a lo subconsciente» (García Calvo, 1991b: 48). No debe sorprender esta estrategia pues, si hacemos caso a Ibáñez (1985: 14), el

Para García Calvo, el Estado, indisolublemente unido al Capital, es la instancia constructora y legitimadora de la Realidad. (El uso de mayúsculas que copio de García Calvo intenta subrayar el carácter ideal y trascendente de los significados.) Por su parte, Bourdieu (1997) ha ido a parar a la misma conclusión con sus observaciones a propósito del Estado al sugerir: primero, que las Administraciones Públicas producen problemas sociales que las ciencias sociales ratifican y asumen como problemas sociológicos (p. 95); segundo, que el Estado es capaz de ejercer su singular y potentísima violencia simbólica porque es capaz de encarnarse, a la vez, en la objetividad observada y en la subjetividad observadora, en este último caso generando estructuras mentales de percepción y pensamiento (p. 98); y tercero, que el Estado es un «metacapital» que concentra capitales coactivos, culturales, simbólicos y económicos (p. 99).

${ }_{8}$ Acerca de la responsabilidad de la ciencia en la represión y olvido del saber-hacer cotidiano también ha hablado Michel de Certeau (1990: 108-111). 
logro de la «anamnesis», «desligar lo que está ligado por represión, liberar las posibilidades de funcionamiento reprimidas por la memoria, transformar la memoria en conciencia», es la operación fundamental de cualquier ciencia, pero especialmente de las sociales, en relación a un inconsciente biográfico (caso de las psicologías) o a un inconsciente histórico (como sucede con las sociologías) $)^{9}$. García Calvo añade que para lograr esta anamnesis el investigador deberá escindirse en Científico, "que baja con sus antorchas a las grutas innominadas de lo subconsciente» (García Calvo, 1991b: 50), y en pueblo, que habla desprevenida e ingenuamente la lengua en que le ha tocado vivir, pues sólo así puede permitir al mundo en el que se habla manifestarse. En sociología, las exigencias que plantea García Calvo al gramático las puede cumplir el investigador utilizando la observación participante.

En cierta ocasión, García Calvo (1995) llamó la atención sobre el hecho de que la voz latina para nombrar al pueblo (populus) tiene una gran proximidad onomatopéyica con la voz utilizada para designar al álamo (poopulus), y explotó esta relación para sugerir que el pueblo o la gente, como el álamo, es trémulo, vaivén, movimiento incesante. La metáfora puede ser comprendida y sentida si pasamos de la descripción sincrónica del lenguaje a una descripción diacrónica en la que los hablantes conversan. En ese momento, los deícticos y otros índices mostrativos que forman parte del mundo en el que se habla (tales como "yo", «aquí», «ahora», etc.) no cesan de moverse y pasar a señalar sujetos, lugares y tiempos distintos. Según García Calvo (1993: 93), "es la perpetua disponibilidad del YO (o de cualquier otro índice) para mudar de sitio o estar en cualquier sitio lo que permite tener a tal índice una inestabilidad similar a las de las partículas elementales». De modo que el mundo en el que se habla se convierte en un torbellino, un sistema metaestable que no cesa de sustraerse a la acción significadora del estable y ordenado mundo de que se habla ${ }^{10}$.

\subsection{Sociabilidades primarias y elaboradas}

La segunda cuestión que paso a aclarar es la relativa al carácter primario/ elaborado de las sociabilidades. Pero para hacerlo será necesario sustituir esos términos por los de acción ritual/normativa y aclarar su significado. Lo haré utilizando a autores que parecen compartir la distinción establecida por García

9 Por su parte, Martín Santos (1988: 221) propuso el término de "anagnórisis» para indicar los momentos en que el poder (quizá como consecuencia de la crisis del sistema de representaciones encargado de legitimarlo) revela su verdadero carácter.

${ }^{10}$ Estamos, pues, ante el caos según lo entienden Deleuze y Guattari (1993: 117): una situación tal en la que lo virtual domina sobre lo actual. En efecto, «el caos se define menos por su desorden que por la velocidad infinita a la que se esfuma cualquier forma que se esboce en su interior. Es un vacío que no es un nada sino un virtual que contiene todas las partículas posibles y que extrae todas las formas posibles que surgen para desvanecerse en el acto, sin consistencia, sin referencia, sin consecuencia». 
Calvo entre los mundos en y de que se habla. En principio, el rito o ceremonial es un acto ejecutivo que, por la aparente mayor importancia que en él posee la praxis, debiera oponerse a los actos expresivos en los que se intuye un mayor grado de mentalismo, de simbolicidad. Al hilo, en cierto modo, de esta distinción, Lévi-Strauss (1976: 604 y ss.) ha mostrado la complementariedad del rito y el mito, pues si éste construye un pensamiento metafórico sobre un eje paradigmático que con su malla simbólica atrapa «lo vivido», aquél con sus operaciones particulares de fragmentación y segmentación capta metonímicamente en un eje sintagmático lo que se escapa, «el vivir».

Sin embargo, esta distinción es sólo parcialmente cierta ya que ni los actos ejecutivos atienden exclusivamente al «vivir» ni los actos expresivos se refieren únicamente a «lo vivido». En efecto, en los actos expresivos, además del mentalismo simbólico que distribuye significados, también interviene de forma decisiva un "trabajo expresivo» aplicado sobre esa "sustancia expresiva» que es el sonido (Martín Serrano, 1982: 15-17) ${ }^{11}$. Por lo tanto, los actos expresivos son, antes que simbólicos, un particular modo de organización de la praxis. Pero es que, además, en el acto expresivo ya ejecutado, la praxis sigue interviniendo. Los etnometodólogos utilizan el término «indexicalidad» para aludir a esa influencia del «vivir» sobre la lengua cuando afirman que «aunque una palabra tenga un significado transituacional, igualmente tiene una significación distinta en cada situación particular»(Coulon, 1988: 39). Quiere esto decir que, además del texto que vehicula lo «vivido», interviene en la producción de sentido el contexto del «vivir». Podemos, por lo tanto, concluir respecto al acto expresivo que se inserta en una unión tensional protagonizada por dos componentes, el «estructural-simbólico» y el «anafórico» (Kristeva, 1981: 104-106). Mientras el primero se refiere al protagonismo de lo "vivido" y es de carácter ideal-abstracto (como el mundo de que se habla y el campo simbólico mencionados antes), el segundo expresa la praxis de base, el «vivir», y tiene dos modos de expresión: uno débil, la anáfora propiamente dicha, que remite a otros enunciados, y otro fuerte, la deixis, que implica una referencia al proceso mismo de la enunciación (Lozano, Peña Marín y Abril, 1989: 95)12. Dicho de otro modo, mientras el componente estructural-simbólico tiende a afirmar la unidad del texto, el componente anafórico lo disgrega remitiendo a otros textos o al contexto.

Pues bien, estos dos componentes, el simbólico y el anafórico, intervienen también en los actos ejecutivos. Éstos pueden ser de dos clases: normativos y

${ }^{11}$ Partiendo del modelo de Martín Serrano, Muñoz Carrión (1988: 31-54) ha propuesto un interesante modelo para una "antropología de la comunicación».

${ }_{12}$ Esta potencia irruptiva y desestructurante del componente anafórico que desborda el poder mentalista del componente estructural-simbólico se puede apreciar en la etimología de la palabra "anáfora», que en griego significa "surgimiento», «elevación», «ascensión» (Kristeva, 1981: 105). Por contra, lo propio del orden mentalista es aislarse, bloquear el ascenso de la praxis y someterse al imperio de la idea, precisamente lo que intenta la «anágoge», figura retórica que en teología se refiere a la interpretación de las sagradas escrituras y que hace pasar de lo literal a lo espiritual impulsando una elevación del alma hacia las cosas celestiales. 
ceremoniales o rituales. La acción regulada por normas da lugar a una actividad que se intenta adecuar a un orden. Ahora bien, esa organización de la acción social puede ser efectuada de forma autónoma por la propia colectividad —es el caso de la acción regulada por la costumbre (Maffesoli, 1990: 52 y ss) — o de forma heterónoma por una instancia exterior —es el caso de la acción regulada con leyes_- En las sociedades sin escritura y sin Estado como los lozi de Zambia, un mismo término, mulao, designa la ley explícitamente coactiva y la costumbre que emana de la propia comunidad (Balandier, 1989: 162). Es, pues, la propia colectividad la que efectúa la ordenación de su actividad. En cambio, las sociedades industrializadas y burocratizadas, en donde "la clasificación y la jerarquía de los hombres y de las cosas» es más imperiosa, "se basan en una simbolización dirigida por instancias de poder separadas de la comunidad» (p. 145). Este mayor predominio del componente estructuralsimbólico es encarnado por la «ley», término que etimológicamente está emparentado con «leer»(lex, legere). Indica, por lo tanto, que debe ser promulgada por un cuerpo de especialistas al servicio del Estado, los que poseen el dominio de la escritura, y obedecida (leída) por la comunidad a la que va destinada ${ }^{13}$.

Para Maffesoli (1990: 46; 1992: 76), la ley es una guía de acción para la historia que está por hacer y cumple la función de mejorar la imperfecta naturaleza humana, pero su exceso de voluntad puede producir efectos contrarios a los deseados: "un racionalismo a ultranza semeja ese exceso de vida que es el cáncer: se desajusta y desajusta todo hasta matar la vida». No obstante, el auténtico límite de la heteronomía que impone el componente estructuralsimbólico a la ejecutividad no es tanto la obtención de efectos perversos como la subsunción de toda la actividad en un plan ideal, lo que Baudrillard (1991: 53) ha denominado "performance interactiva»: "la misma acción tiene menos importancia que el hecho de que sea producida».

Si la actividad normativa da cuenta de los actos ejecutivos de la sociedad, la actividad ritual tiene más que ver con la organización alternativa de la sociabilidad que se efectúa en la socialidad. Hay también, como sucede con la acción normativa, cierto grado de estructuración. Sin embargo, ésta no está regulada desde el exterior, como sucede con la ley y, en cierto modo también, con la costumbre. Son los propios sujetos los que crean los rituales o ceremoniales y quienes utilizando ciertos procedimientos interpretativos y decisorios trabajan para sostenerlos ${ }^{14}$. Todo ello indica que el componente anafórico (el

${ }_{13}$ Mientras el «derecho familiar» se nombra en griego themis, el derecho aplicado a los ciudadanos es denominado en latín con el término dico y en griego con dike. En ambos vocablos se alude a un mostrar verbalmente y con autoridad lo que debe ser (Benveniste, 1969, 2: 107-109). Si dico y dike se emparentan con decir (dicere) e indican un dominio del que habla sobre el que escucha - «el lenguaje de la autoridad, dicen los uruburu, es un ne eng hantan, un lenguaje duro, que no espera respuesta» (Clastres, 1974: 41)—, con lex se alude a un dominio del que escribe (o hace escribir, caso del dictador) sobre el que lee.

${ }^{14}$ Como han señalado los etnometodólogos (Coulon, 1988: 32-33; Cicourel, 1979: 37-42), incluso en las acciones normativas es necesario reconocer el proceso concreto por el que se recrean los objetivos que marcan las normas. 
mundo en el que se habla, que diría García Calvo) es más importante que el estructural-simbólico.

\subsection{El objeto de la investigación}

Aclarada la naturaleza refractaria del pueblo y por qué unas sociabilidades son primarias y otras elaboradas, hay que proponer un objeto de estudio y un método que permitan analizar la alteridad juvenil. Por lo que al objeto respecta se trata de elegir, no arbitraria ni aleatoriamente, sino intencionadamente, aquel en el que mejor y más fácilmente presumamos que nos vamos a poder encontrar con la juventud en tanto que alteridad. Pues bien, hay varios objetos que, en principio, pueden resultar de interés. Por un lado, puede prestarse atención al tribalismo juvenil, actividad que, para ser correctamente comprendida, debe ser contrastada con un hecho político de gran calado: la falta de interés de los jóvenes por la política instituida, manifestada por sus altos índices de abstención electoral, las bajas tasas de afiliación a partidos políticos, sindicatos e incluso asociaciones y su escepticismo respecto a la política instituida en general ${ }^{15}$. Se trataría entonces de descubrir la alteridad juvenil observando no sólo cómo los jóvenes huyen de la sociedad instituida y la deslegitiman, cuestión de la que las encuestas dan suficiente y abundante cuenta, sino también cómo inventan socialidad. Sin embargo, la actividad que quizás mejor puede permitir comprender la alteridad juvenil es la diversión, que, en este caso, tiene como correlato en la sociedad la extinción de la ética del trabajo. A ella dedican los jóvenes españoles el 40 por 100 de sus rentas y una parte importante de su tiempo ${ }^{16}$.

15 De 1970 a 1990, el porcentaje de quienes se sacrificarían por la patria luchando en una guerra pasó en el conjunto del Estado del 60 al 39 por 100 (Alaminos, 1994: 73). Por otro lado, de 1960 a 1982, período que abarca el final del franquismo y la primera fase de la Transición Democrática, el porcentaje de jóvenes que mostraba poco interés por la política aumentó de un 76 a un 86 por 100 y la afiliación sindical bajó del 12 al 9 por 100 (Fundación Santa María, 1984: 197 y 45). En ese último año, 1982, tan significativo para la segunda fase de la Transición, apenas un 2 por 100 de jóvenes entre 15 y 20 años confesaba estar realmente interesado por la política (Prieto Lacaci, 1985: 103), y seis años más tarde se comprobó que una tercera parte de los jóvenes no tenía por ella el más mínimo interés (INJUVE, 1991: 122-123). En cuanto al asociacionismo, nos encontramos con que es más importante el deportivo o cultural que el directa o indirectamente relacionado con la política. Aunque desde mediados de los ochenta se ha constatado un creciente interés por el asociacionismo, pues en 1982 afectaba a un 25 por 100 y en 1991 a un 37 por 100 (Prieto Lacaci, 1985: 44; INJUVE, 1991: 124), la tasa de asociatividad juvenil es sensiblemente inferior a la de los adultos (FOESSA, 1994, 2: 1994) y aún queda entre los jóvenes urbanos un 66,5 por 100 que no ha pertenecido nunca a ninguna asociación (Prieto Lacaci, 1991: 247-252). Según opina un experto, esto sucede porque anteponen el estar con los amigos al vínculo asociativo (Prieto Lacaci, 1991: 217-221). ¿Es esto un defecto o una virtud?

16 Véanse Zárraga (1986: 245), Navarro y Mateo (1993: 133-143) y Martín Serrano (1991: 39-40). Sobre la importancia cultural y psicológica de la diversión, véanse Huizinga (1972), Winnicott (1993), Fink (1966) y Piaget (1986). 
Elegida la diversión de los jóvenes como objeto de estudio, es necesario seleccionar una práctica lúdica concreta. En mi opinión, quizás la más adecuada sea la diversión en las discotecas, que tanto en 1983 como en 1992 atraía a 6 de cada 10 jóvenes españoles de entre 15 y 24 años (Muñoz Carrión, 1994b: 254-256). Además, las discotecas, a diferencia de las verbenas, son espacios semicerrados y oscuros construidos al margen del acontecer de la sociedad y capaces de generar un universo propio, en gran medida impermeable a toda influencia exterior (Muñoz Carrión, 1985, 1994a: 179-227). Quiere esto decir que los ceremoniales que allí tienen lugar responden, al menos en principio, a una lógica que no es la heterónoma o impuesta del exterior (con leyes y costumbres), como sucede en la sociedad, sino a una más autónoma que facilita la creación, recreación o invención de rituales.

Para apreciar mejor la disidencia sociocultural que la alteridad juvenil tiende a protagonizar en esos espacios decidí investigarlos y comparar sus ceremoniales con los que ejecutaban los adultos en similares locales, aprovechando el privilegiado puesto de observación que permite el trabajo de camarero. Siguiendo a Caillois (1967), observé y comparé entre 1989 y 1991 en la discoteca But y en la sala de fiestas Pasapoga, ambas en Madrid ${ }^{17}$, tres de las cuatro clases de comportamientos lúdicos por él distinguidos: el agon, el ilinx y el mimicry. En relación al agon analicé la relación entre los géneros, las relaciones entre iguales y el trato con los objetos; en cuanto al ilinx presté atención a la alteración del estado de conciencia ordinario lograda con el consumo de drogas; y por lo que respecta al mimicry me interesé por la función otorgada al vestuario en la presentación pública de los sujetos. Además, consideré también necesario hacer referencia a los usos del espacio y a las músicas y bailes con los que jóvenes y adultos se divertían.

Una vez obtenida la información decidí tratarla averiguando respecto a qué tenía lugar la disidencia juvenil en cada uno de los ceremoniales. Para ello me vi obligado a descubrir en cada ceremonial cuáles eran los contenidos activados por los adultos y los jóvenes para dar a sus prácticas una estructuración y unidad de sentido que resultaran aceptables a los participantes. En el caso de los adultos concluí que los sentidos derivaban de ciertos pilares socioculturales emblemáticos de la modernidad e incluso de la occidentalidad. Tendía entonces a primar en ellos el componente estructural-simbólico y la obediencia a cierta realidad instituida. Así que eran más elaborados y permitían reproducir el orden cultural. En cambio, entre los jóvenes era obvio que disentían de ese

17 El trabajo como camarero me permitió una "participación observante» (Cicourel, 1982: 75-76) no del todo «emic» pero sí útil. En Pasapoga (Gran Vía, 37 —al lado del cine Avenida-) trabajé seis días a la semana de febrero a junio de 1991, y en But (Barceló, 13 —al lado de la discoteca Pachá-) los jueves, viernes, sábados y domingos desde noviembre de 1990 a enero de 1991. Al primer local acudían regularmente adultos de 40 o más años, mientras que la edad del jóven público que acudía a But las tardes de los fines de semana (por las noches y el resto de la semana el público era diferente - lo componían aficionados al baile de salón-) oscilaba entre los 16 y 20 años. 
orden, pero me resultó imposible en bastantes casos averiguar qué contenidos eran activados. Esto se debió a que en sus ceremoniales la influencia del componente anafórico era mayor y a que el componente simbólico era más débil. De modo que los ceremoniales eran más primarios y expresivos. Así que si los adultos reproducían una realidad ya instituida, los jóvenes inventaban nuevos modos de estar en el mundo.

\section{ESPACIOS LISOS Y ESTRIADOS}

Aunque But y Pasapoga son, desde un punto de vista arquitectónico, muy similares, ambos espacios son vividos y apropiados de forma bastante diferente. Son similares porque, en los dos casos, el círculo de la pista de baile, situada en un extremo de la planta baja, es el que permite la distribución centrípeta de la mayoría de los lugares por los que transitará el público. Ese poder magnético del centro es, además, el que más atrae la luz y sobre el que más intensamente se orienta la música. Y, en segundo lugar, el acceso desde el exterior hasta el centro de la planta baja exige en los dos locales, como en un ritual iniciático, el descenso y el paso por tres fronteras que el cliente debe salvar. En la primera, situada en la misma puerta de la vía pública, un vigilante decidirá, según el código de estilo de la sala, si el solicitante puede o no entrar; en la segunda frontera, la taquilla, los clientes deberán abonar cierta cantidad de dinero para poder entrar; y en la tercera, el servicio de guardarropa, el cliente se despojará de prendas de abrigo, bolsos y demás accesorios que traía del exterior. Tras franquear estas tres fronteras, y al modo como en los ritos de paso el sujeto se convierte en iniciado, cada cliente es separado del exterior y convertido en poblador del espacio interior.

Además de la similitud arquitectónica, los espacios de But y Pasapoga comparten un imaginario topológico idéntico. Hay en los dos casos el descenso por debajo de la superficie a un interior oscuro, curvo y torneado que, si hacemos caso a las sugerencias de Durand (1984: 274-277), debe remitir al arquetipo lunar de la caverna, sostenido por las imágenes del vientre materno y de la madre tierra. Esa imagen intrauterina expresa el sueño de retornar a los orígenes y de renacer por lo que transgrede imaginariamente la Ley solar, la del padre, la que funda cualquier orden (Alcázar, Trabada y Camacho, 1993). Según lo expuesto más atrás, esto quiere decir que el imaginario invocado por los espacios de But y Pasapoga no pertenece al orden instituido en la sociedad, sino a ese otro espacio en el que suceden cosas menos previsibles, la socialidad.

Si se da importancia no tanto a las características comunes de los espacios construidos sino a las propiedades que crean los clientes con sus usos y apropiaciones, se pueden contrastar las competencias socioculturales de jóvenes y adultos. Para hacerlo trabajé información relativa a los componentes de subjetivación utilizados para dar forma al espacio y a la matriz experiencial que resultó más apta para desenvolverse en ellos. Respecto al primer asunto, resultó 
bastante claro desde el principio que los adultos de Pasapoga se incorporaban al espacio adaptándose con bastante fidelidad a los usos y finalidades instituidos, por lo que la autonomía ejecutiva no era tan intensa como entre los jóvenes. En efecto, los adultos sólo bailaban en la pista, sólo se sentaban en las sillas y sillones, las escaleras eran respetadas como lugares de tránsito, a los lavabos sólo se iba para asearse o arreglarse (dejando siempre la puerta cerrada), etc. Había, pues, un respeto estricto de la correspondencia entre usos y lugares establecida por el diseño arquitectónico y, en último término, un acatamiento de las convenciones sociales. En cambio, en But todo era bien distinto. En efecto, los jóvenes no sólo bailaban en la pista, sino que aprovechaban el escenario y cualquier otro lugar de las dos plantas para hacerlo, e incluso algunas chicas solían subirse a los altavoces del escenario. Aunque aprovechaban los sillones y las cómodas para sentarse, también lo hacían en las mesas o en cualquier lugar que encontraran a mano. Por otro lado, lugares de tránsito como las escaleras y el pasillo de la salida de emergencia eran también ocupados, impidiendo circular por ellos con comodidad. Y los lavabos solían tener las puertas exteriores casi siempre abiertas, pues también resultaban útiles como improvisados espacios de reunión.

En cuanto al tipo de subjetividad activado por los clientes para acoplarse al espacio instituido hay que decir que los adultos de Pasapoga se veían afectados por el principio de individuación, mientras que entre los jóvenes de But tenía más importancia el de masividad. Y conviene añadir que en ambos casos la sala invitaba a las subjetividades a organizarse de ese modo. En el caso de Pasapoga había una gran cantidad de sillas y casi 200 mesitas redondas repartidas por las dos plantas, a las que se podían añadir dos decenas más. A los adultos de Pasapoga, sobre todo a las mujeres, parecía gustarles pasar gran parte del tiempo sentados frente a una mesa, y es por eso que los maitres ponían un cuidado especial en hacer que en la sala cupiera el máximo número de ellas. No obstante, el interés real del cliente era el de poseer un sitio propio en el que poder estar con su consumición y desde el que eventualmente moverse. En último término, lo que los adultos de Pasapoga deseaban era poseer lugares individualizados, su propio territorio, y es por esto que solían ser muy escrupulosos en la elección y toma de posesión del lugar.

Por lo que respecta a la experiencia que se hacía del espacio, los adultos de Pasapoga la activaban casi exclusivamente desde el sentido visual, mientras que entre los jóvenes de But intervenían, además de ése, otros sentidos. Y como en el caso de los componentes de subjetivación, también nos encontramos aquí con que la expresión de tales competencias era favorecida por el espacio instituido. En el caso de Pasapoga la luz era intensa, lo que permitía observar con bastante comodidad cualquier rincón de la sala. Por otro lado, el volumen de la música no era muy alto, por lo que se podía conversar cuanto se quisiera sin problemas. En último término, del mismo modo que trasladan la función individuo con que transitan por la sociedad al interior de Pasapoga, también la jerarquía de los sentidos con que ordinariamente se desenvuelven es utilizada 
en este local para divertirse. Partiendo de este predominio de la visión, se puede hablar de un espacio creado con la mirada en el que es posible distinguir cuatro zonas. Una en la que el sujeto "ve y es visto»; otra poblada por los mirones, que "ven sin ser vistos»; una tercera destinada a los exhibicionistas en la que el cliente "es visto pero no ve», y una cuarta, más íntima, utilizada por las parejas, en la que el adulto "ni ve ni es visto». Este espacio "estereoscópico", construido democrática y activamente por los clientes aprovechando las posibilidades que ofrece el diseño arquitectónico, no es muy distinto del que espontáneamente tiende a construirse en la vía pública, tal como Mairal (1995) ha mostrado en su estudio de una pequeña ciudad española, pero sí que se diferencia radicalmente de la mirada unidireccional, del "ver sin ser visto", que crea el autoritario espacio "panóptico" (Foucault, 1986: 199-230) y que hoy la videovigilancia tiende a intensificar (Lyon, 1994: 167). Mientras el primero forma parte de la socialidad, el segundo es una pieza clave del orden disciplinario instituido en la sociedad por la modernidad

Por lo que se refiere a la apropiación del espacio realizada por los jóvenes de But, tanto respecto a los componentes de subjetivación utilizados como a la matriz experiencial activada, nos encontramos con diferencias importantes. La función individuo no resulta válida para explicar cómo los clientes de But ocupaban el espacio. Si en Pasapoga el personal se preocupaba de poner a disposición de los adultos cuantas mesas y sillas hicieran falta para colmar su deseo de individuación, en But la práctica habitual era justamente la de desindividualizar el espacio. Nada más entrar en la sala, uno de nuestros primeros trabajos consistía precisamente en retirar los ceniceros y llevar al almacén de la planta baja todas las sillas, casi todos los taburetes y algunas mesas. De esta manera se creaba un espacio mucho más abierto y difícil de individualizar, que sólo ofrecía a los sedentarios los asientos fijos empotrados y las barandillas acolchadas situadas enfrente de las barras. El resto de la sala, en lugar de por individuos, era poblada por una masa nómada y bulliciosa en la que la distancia personal era abolida y que a los encargados de mantener un mínimo de orden nos hacía trabajar mucho más intensa y menos cómodamente que en Pasapoga.

Si la función individuo respetada por los adultos de Pasapoga es uno de los referentes más importantes del plan que inspira el orden trascendente de la sociedad, la masa en que se inscriben los clientes de But es uno de los modos como suele expresarse la socialidad. Si hacemos caso a Canetti (1982a), la masa es el lugar donde el individuo que puebla la sociedad se redime de su aversión al contacto. En La antorcha al oído, la segunda parte de su autobiografía, confiesa haberse sentido "pasta blanda" ante la presencia de la masa: "La masa me había subyugado; era un delirio en el que uno se perdía y olvidaba, sintiéndose monstruosamente vasto y a la vez colmado; lo que uno sentía no lo sentía para sí: era una especie de altruismo absoluto" (1982b: 100-101, 127 y 152). Entre los jóvenes es obvio que, al contrario de lo que suele suceder con los adultos, la masa atrae. Esto quizá suceda porque el instinto que les incita a 
reforzar la función individuo es menos poderoso que el que les empuja a fundirse en la masa y desindividualizarse ${ }^{18}$. El efecto masa impedía en But no sólo la expresión de la función individuo, sino también que el sentido visual dominara a los otros en la percepción del espacio y la posibilidad de entablar un trato conversacional fluido. En todo ello abundaba también el ambiente luminoso y acústico que ponía en marcha el disk jockey. Su altísimo volumen y las ráfagas de flashes forzaban a que los sujetos abandonaran el control de sus sentidos y percibieran como mejor pudieran. Por todo ello, la experiencia del entorno se hacía conjugando por igual todos los sentidos. Ahora bien, ¿cuáles son las sustancias significantes productoras de sentido en los usos y apropiaciones dados al espacio?

McLuhan (1985: 28-33, 50-55) propuso los términos «hiperestesia»y "sinestesia» para designar dos modos de organizarse los sentidos que son responsables de dos tipos de orden social diferentes. El primero, que privilegia la percepción visual, nace en Grecia al implantarse el alfabeto, pero será tras la invención de la imprenta, en el siglo XVI, cuando alcanzará su mayor dominio sobre la vida social de Occidente. Las artes, las técnicas, el pensamiento, la religiosidad, la política y la misma subjetividad serán transformadas. En cambio, la sinestesia se basa en un despliegue no jerárquico de los sentidos desde una matriz «audio-táctil» (de la que se emancipó la vista) y permite una experiencia del entorno más compleja e intensa. Su hábitat es la cultura oral no alfabetizada y se caracteriza por dar lugar a un arte, un pensamiento, una religiosidad, una subjetividad y un estilo de vida más vinculados a la materia, menos trascendentes. Según esto, la experiencia espacial de los adultos de Pasapoga, al hacer predominar el sentido visual, no hace sino mantener en su diversión el dominio de la hiperestésica cultura occidental, mientras que los jóvenes de But, al liberar más sentidos, retrotraen la experiencia del espacio a un estadio cultural para-, extra- o prealfabético.

Sin embargo, quizás no sea éste el modo más apropiado de evaluar la disidencia sociocultural juvenil. Una aproximación distinta es permitida por la distición entre espacios «lisos» y «estriados» realizada por Deleuze y Guattari (1988: 483-506), desarrollando una sugerencia del compositor Pierre Boulez, y que intenta diferenciar dos estilos de vida, el sedentario y el nómada, que en cualquier ámbito son los que, respectivamente, estrían y alisan los espacios. Desde esta otra perspectiva se puede comprobar con facilidad que los adultos aceptan y reproducen un espacio "estriado" ya dado, mientras que los jóvenes tienden a crear un espacio «liso». En principio, del mismo modo que la percepción es sinestésica, el espacio es liso, ya que cualquier dirección o posición puede ser trazada en él. No obstante, sus pobladores tienden a estriarlo u ordenarlo creando trayectorias más probables, separando lugares, diferenciando posiciones, etc. Pero la operación de estriaje nunca es perfecta debido a que el espacio tiende inercialmente a alisarse y, sobre todo, porque ciertos pobladores efectúan operaciones de alisamiento. Según esto, son sedentarios aquellos

18 Véanse Yonnet (1988: 126-130) y Bajtin (1990: 229). 
pobladores que moran y transitan por los lugres y caminos recomendados (u ordenados) en lugar de por los desaconsejados (o prohibidos), mientras que son nómadas quienes inventan nuevas moradas y trazan nuevas sendas o no respetan las instituidas. Los adultos pertenecen a la primera clase de individuos y los jóvenes a la segunda.

\section{LAS MÚSICAS Y LOS BAILES}

Además de un orden espacial, But y Pasapoga proponen a sus clientes una organización del tiempo, más exactamente una sucesión de tres intervalos temporales (la recepción, el tiempo central y la despedida), que es básicamente idéntica en las dos salas. Ese orden está puntuado por la música y, como el diseño arquitectónico del espacio, es también formalmente muy parecido al instituido en otras discotecas o salas de fiestas. Sin embargo, el tipo de música propuesto a los dos tipos de clientes y los bailes ejecutados para acompañarla son bien diferentes.

Respecto a los tipos de música, en Pasapoga el disk jockey solía iniciar el primer intervalo con temas soul y funk. En la segunda parte, la elección de la música corría a cargo de las orquestas que contrataba la sala. Este tiempo central era el más apreciado por los clientes pues tenían oportunidad de bailar y disfrutar con el tipo de música que más les gustaba (temas pop de los sesenta y música bailable nacional o latinoamericana). Finalmente, la última media hora, la sala proponía un bloque de temas para ir despidiéndose de los clientes, que el disk jockey iba cambiando cada semana según lo sugerían las listas de superventas y la aceptación que entre el público tuvieran los nuevos temas. $\mathrm{Al}$ margen de la música soul y funk inicial, que respondía más al gusto del disk jockey que al de los adultos, el resto de los temas propuestos por la sala y las orquestas se encuadran en tres tipos de música popular. Por un lado, la música pop de los años sesenta, que debió modelar la «memoria musical» (Levices Mallo y Serrano Pascual, 1993: 9-10) de esa generación afectando de un modo decisivo al gusto desarrollado desde entonces. Por otro lado, el gusto de estos adultos se orientaba también hacia la música popular nacional, en particular la andaluza, para la que necesitaban activar no la memoria musical generacional, sino la cultural, de mayor alcance. Y se entusiasmaban también con la música popular centroamericana.

Por lo que respecta al baile pude comprobar que si gran parte de los adultos de Pasapoga le daban un valor expresivo, otros tendían a hacerlo formar parte de los ceremoniales de seducción, por lo que su valor era instrumental. Por otro lado, también observé que la gran mayoría tenía un gran interés en ejecutar los bailes con la máxima corrección, adecuando sus movimientos a los códigos establecidos para cada estilo. Esta codificación de los movimientos era bastante simple en los bailes individuales y muy exigente en los bailes de pareja. Los primeros permitían construir gestos encadenados que servían para 
acompañar al componente melódico de la música, mientras que los segundos obligaban a acoplar secuencias de gestos distintas que permitían reproducir el componente armónico. En fin, el disfrute del baile tiene en los dos casos que ver con la obediencia de ciertos códigos.

En But, aunque la distribución de los intervalos temporales era similar a la de Pasapoga, cada uno de ellos estaba ocupado por músicas muy diferentes. El jovencísimo disk jockey solía proponer para la primera parte temas de grupos españoles con gran éxito de ventas entonces. En la siguiente fase, el disk jockey ponía a prueba su pericia pinchando los temas que más gustaban al joven público de But y tensando el ambiente con juegos de luces. En este tiempo la pista de baile estaba permanentemente ocupada y la actividad era frenética. Los temas pinchados pertenecían al tipo de música que genéricamente se denomina technomusic y que engloba muchos subestilos. El último intervalo estaba ocupado, al principio, por el mismo tipo de música, pero la luminosidad era menos agresiva, y poco a poco se iba sugiriendo, con temas rítmicamente más calmados, que se podía ir comenzando a desalojar la sala.

Los tipos de música que se escuchaban en But y Pasapoga tenían en común el pertenecer a la clase de música que antes he denominado popular. Sin embargo, al contrario que los adultos, entre los jóvenes ese gusto daba la impresión de estar mucho menos influido por la costumbre. La razón es que desde los años cincuenta el gusto de los jóvenes españoles se ha adherido a modas siempre nuevas. Este exilio de la costumbre tiene mucho que ver con el desarrollo que ha alcanzado la industria discográfica, pero no conviene concluir de esa relación que los jóvenes son manipulados por las grandes multinacionales pues también ellos ponen algo de su parte para que esa música les guste. La música con la que comenzaron a huir los jóvenes de los gustos estandarizados fue el rock and roll, influido por la música negra norteamericana, y especialmente por el blues. Con esta música los jóvenes tuvieron acceso a un modo mucho más expresivo y directo de abordar el tema sexual. Pero nació también con ella un nuevo baile (como el "paso del pato" de Chuck Berry), un nuevo look (el tupé de Elvis) y, en fin, un nuevo estilo de vida (Yonnet, 1988: 108 y ss.). De todas formas, no es éste el tipo de música que gustaba a los jóvenes de But. Sus preferencias se orientaban hacia la música techno, que, acompañada por una luminosidad frenética y el consumo de drogas, desencadena intensas y primarias emociones. Según Levices Mallo y Serrano Pascual (1993), la música house, el techno y el rap gustaban en 1990 a 3 de cada 10 jóvenes españoles. Pero lo más importante es que ese gusto parecía oponerse frontalmente al rock, tan emblemático entre las generaciones anteriores de jóvenes.

Aunque menos conocida que el rock, la música techno tiene ya algo de historia y un futuro prometedor. Según Lles (1994: 59-64; 1995: 77-81), los orígenes de esta música basada en máquinas podemos encontrarlos ya en 1913, cuando Luigi Russolo creó la machina intonarrumori, «un increíble y complejo artefacto que emitía extraños sonidos». Pero, más cerca de nosotros, la máqui- 
na que ha permitido hacer despegar los sonidos discotequeros actuales fue el sintetizador Moog. Armados con estas máquinas, en Berlín, Colonia y Düsseldorf, grupos como Tangerine Dream y Kraftwerk experimentaron con la «música espacial» y los sonidos electrónicos. Por otro lado, en Estados Unidos, ciudades como Detroit, Chicago y New York darán el espaldarazo a estilos como el latin house y el hip house, que mezclan la música cibernética con la étnica de los hispanos y de los negros. Y, finalmente, en Gran Bretaña las fiestas clandestinas (raves) y el consumo de LSD o de drogas sintéticas crearán el ambiente que necesita el acid house, música con un ritmo «excitante, machacón y crujiente» que en poco tiempo se convertirá en la enseña de la nueva contracultura musical. Este último tipo de música llegará a Ibiza en el verano de 1988 y en el invierno del mismo año a unas cuantas discotecas madrileñas (Robles, 1993: 34).

Pasando al baile, utilizado para hacer experiencia de esta música, también aquí nos encontramos con que es muy diferente al que ejecutan los adultos de Pasapoga. En efecto, si entre éstos se practica el baile en pareja y en menor medida el grupal, aquéllos apuestan exclusivamente por el individual. Entre otras cosas, esto quiere decir que el baile no es aquí considerado como instrumento para el encuentro sexual y que, por lo tanto, satisface únicamente necesidades expresivas. Por otro lado, tampoco se da la exhaustiva regulación de movimientos que observé en los bailes ejecutados por los adultos de Pasapoga, pues los gestos corporales son bruscos, a menudo convulsos, se encadenan por repetición y no construyen ninguna secuencia melódica. Se trata, pues, de un baile débilmente codificado que no exige tanta competencia técnica como el de los adultos y que permite hacer experiencia directa del componente más primario de la música, el ritmo ${ }^{19}$.

Difieren los bailes de But de otros que en los años cincuenta entusiasmaban a los jóvenes, como el rock and roll, el twist (popularizado por Chubby Checker) y el booggie wooggie (bailado ya en los años treinta), pues requerían cierta pericia y el respeto de algunos movimientos básicos. Tampoco tiene mucho que ver el baile de los jóvenes de But con el ejecutado en los años setenta, para acompañar en el mismo tipo de locales la música disco, pues también los gestos y movimientos estaban controlados por códigos bastante elaborados (recuérdense los bailes de John Travolta en Fiebre del sábado noche). Quizás tenga más que ver con el breakdance, inventado para acompañar la música rap, pues hay breves secuencias de gestos que, entre acrobacia, y acrobacia permiten dar un respiro a los ejecutantes y ofrecer al espectador sencillas frases melódicas y rudimentarios acoples armónicos. En último término, lo que permite diferenciar este baile de otros es un estilo muy particular que, a pesar de

19 Acerca de los componentes armónicos, melódicos y rítmicos de la música, véanse Deleuze y Guattari (1984: 487), Derrida (1986: 251), Durand (1984: 254-256) y, sobre todo, Nietzsche (1987: 250-258), para quien el ritmo es el elemento dionisíaco por excelencia. En relación a la música pop, véase Skoff Torgue (1977), y sobre la importancia del ritmo en el acid house, véase Maffesoli (1992: 181-202). 
permitir una gran autonomía a sus ejecutantes, parece responder a cierto modo de entender el acompañamiento de la música ${ }^{20}$.

Según todo lo expuesto, resulta bastante claro que los bailes y las músicas de los jóvenes de But y de los adultos de Pasapoga eran sustancial y formalmente distintos. Es cierto que el interés de los adultos por la música popular se opone al gusto culto y distinguido que más valora la sociedad y que en la práctica del baile se concede más importancia al componente melódico que al que es central en la música clásica, el armónico. No obstante, esta disidencia de los adultos debe ser relativizada pues su gusto musical está anclado en la costumbre y, por lo que respecta a sus bailes, requieren el dominio de ciertos códigos. Por lo tanto, hay una realidad exterior que todavía interviene y media decisivamente en el disfrute de los adultos. En cambio, el gusto musical de los jóvenes de But es más disipativo pues huye no sólo de la música culta, sino también de la popular asimilada a la costumbre, como sucede con el rock. Pero es que, además, su espontáneo y expresivo baile huye también del respeto a los códigos, no presta tanta atención a la articulación melódica y permite una experiencia más intensa del ritmo. Hay, pues, mayor disipatividad y expresividad en las músicas y bailes juveniles que en los de los adultos.

\section{AGON I: LOS ENCUENTROS ENTRE VARONES Y MUJERES}

Aunque pueda resultar extraño, entiendo que las relaciones entre los géneros, y más exactamente los rituales de seducción, deben ser inscritos en el agon de Caillois (1967), así que han de ser considerados como una forma de violencia de carácter "interespecífico», si hacemos nuestra la clasificación de Lorenz (1972: 32) y la adaptamos a nuestros intereses. En efecto, aunque la relación «natural» entre los géneros sea complementaria y gire en torno a la diferencia genital, en las sociedades patriarcales o falocéntricas interviene una violencia simbólica, expresión de otra de base bien real, que torna la relación jerárquica (Irigaray, 1992: 69; Freud, 1980: 128; Balandier, 1975: 36).

Al margen de los motivos que tuvieran los adultos para ir a divertirse a Pasapoga, lo cierto es que todos, con mayor o menor agrado, estaban obligados a ejecutar cierto ritual de cortejo y, con él, a aceptar el modo como la sexualidad era re-presentada (vuelta a presentar). El ceremonial constaba de fases rigurosamente definidas y encadenadas. En principio, tal como prescribe de comienzo a fin el ritual, la mujer adoptaba una pose pasiva, a la espera, mientras que el varón estaba obligado a ser activo, a estar "al acecho», a "conquistarla». Ella esperaba en las sillas y sillones próximos a la pista de baile hasta que la orquesta, iniciando su repertorio habitual, terminaba con la música de

20 Dan la impresión de ser bailes tan expresivos y faltos de código como los de las ménades griegas o los de los jóvenes balineses. Véanse, respectivamente, Dods (1986: 254-255) y Mead (1993: 115-124). 
ambiente. El varón, apostado en la barra o en las mesas más alejadas, apuraba su consumición observando el ambiente y a las mujeres. Una vez que la música y el alcohol parecían haber distendido el anónimo ambiente inicial, los varones comenzaban su merodeo rutinario por las mesas cercanas a la pista acercándose poco a poco, y disimuladamente, a quienes habían decidido convertir en objeto de conquista. Esta fase previa de observación y selección era ejecutada activamente por todos los varones que se embarcaban en el ritual y, con mayor o menor pasividad, por todas las mujeres.

El éxito o el fracaso venía después, en el comienzo propiamente dicho del ritual, cuando los varones las invitaban a bailar. En ese momento la mujer optará por aceptar la invitación o por rechazarla, bien por no considerar adecuado al galán, bien porque rechaza el ritual mismo. En el caso de que la mujer aceptara la solicitud de baile del varón se levantará del asiento sin apenas mirar a su solicitante y, dándole la espalda, se encaminará hacia la pista de baile, donde le esperará. La relación entre los actores en esta fase es fría, extremadamente cortés y absolutamente desfiguradora de su fin sexual. Aun así, lo habitual es que la sexualidad, por más voluntad que se ponga en ocultarla o apartarse de ella, planee continuamente sobre el baile, asomando y desapareciendo, espontáneamente o por voluntad expresa de los actores. Una vez consentida la petición de baile la intención sexual ritual sera subrayada por el ambiente. El bloque de temas con ritmos lentos interpretados por la orquesta y la tenue luminosidad favorecerán la distancia «íntima» (Hall, 1987: 39-54) y la comunicación no verbal que espontáneamente se establezca entre los actores. En este punto el varón podrá simplemente conversar o intensificar la intimidad de la relación. En el caso de que la mujer rechace esta intimación, para el varón no quedará más remedio que la retirada y el abandono en esa fase del cumplimiento del ceremonial. En el caso de aceptación tácita de la mujer, la intimidad irá in crescendo con la sucesión de los temas y su actitud tenderá a dejar de ser pasiva, pues pasará a colaborar en el juego y permitirá erotizar el ritual. Sin embargo, llegados a este punto no se sigue que la relación sexual que el varón demanda vaya a ser atendida, ni siquiera que comiencen los abrazos, caricias y besos. Nunca pude observar escenas de esta clase en la sala, ni siquiera en los reservados del piso superior.

El público mayoritario de $B u t$ ponía en marcha un encuentro entre los géneros muy diferente al que escenificaban los adultos de Pasapoga. Frente al estricto cumplimiento del ritual de seducción que exhibían los adultos, con los jóvenes me fue imposible ordenar la actividad del encuentro sexual según ningún modelo. Esto no quiere decir que la praxis fuera absolutamente libre, sino que la heteronomía era menos importante. En parte, el contexto en el que se desenvolvían los jóvenes explicaba la imposibilidad de ejecutar ningún ritual de seducción tan formalizado como el de los adultos. El volumen de la música, su mismo ritmo, los bruscos juegos de luces, la masificación, etc., creaban un ambiente en el que se hacía imposible el merodeo, el cálculo de distancias, la observación atenta, el diálogo y un baile rítmico que favoreciera el contacto. 
Esto no quiere decir que el joven no tuviera predisposición para ligar. En los inicios de la velada era fácil oír entre amigos y amigas los planes en ese sentido para la tarde y ver miradas furtivas hacia tal o cual joven del género opuesto. Sin embargo, la actividad juvenil parecía abierta a esta y otras posibilidades que se presentaran. Quiere esto decir que, a diferencia de los adultos, estos jóvenes no poseían un plan tan predeterminado al respecto y que el grado de espontaneidad y disipatividad era mayor.

Atendiendo a las fases del ritual de seducción practicado por los adultos pude constatar varias diferencias. En primer lugar, al comienzo no había una separación de espacios para chicos y chicas pues todos y todas frecuentaban los mismos lugares sin distinción. Por otro lado, el contacto solía ser más informal, directo y espontáneo. Un joven relaciones públicas, reconocido por mis compañeros como un consumado especialista en el "arte» de la seducción, solía comentar que no ejecutaba ningún plan, sino que se acercaba a quien le interesaba y "echaba unas risas» que la aludida solía atender. Una vez que tenía lugar el contacto entre chico y chica seguía sin aparecer la formalidad ritual en que se apoyaban los adultos. Es más, parecía no haber siquiera finalidad sexual y que la pareja se abría a otras posibles finalidades. Aunque es cierto que los jóvenes parecían jugar con la intención sexual, en algún momento otros fines, como el baile, el consumo de drogas o la adscripción a uno de los respectivos grupos de origen, tenían también cabida. Por eso la elección o irrupción del fin sexual era menos previsible que entre los adultos. En efecto, unas veces, por la manera de gesticular, la proximidad entre los actores y el modo de acoplarse sus movimientos, deducía un inminente contacto sexual que no se llevaba a cabo, bien porque se había disuelto la pareja o se había elegido otra actividad, mientras que en otras ocasiones encuentros aparentemente casuales mantenidos con gestos, distancias y expresividad menos «cálidos» desembocaban en rápidas intimaciones. Había, pues, una gran indeterminación en cuanto a la previsibilidad del contacto sexual que tenía que ver con la no hegemonía de la sexualidad en las relaciones entre los jóvenes. Por último, una vez decidida o asomada la finalidad sexual de la relación, los jóvenes se apartaban de otro aspecto fundamental que tienen en cuenta los adultos: la ocultación de su práctica. Frecuentemente podían observarse escenas de besos, caricias o abrazos en cualquier lugar de la sala que esporádicamente desembocaban en preludios sexuales y que, en alguna ocasión, los camareros cortábamos por indicación del maitre. Por otro lado, la relación sexual podía tenerse en cualquier lugar mínimamente resguardado de miradas.

En el ceremonial descrito la disidencia sociocultural juvenil afecta al patriarcalismo y a la represión de la sexualidad. Por lo que respecta al patriarcalismo, conviene hacer notar que el falocentrismo, su más potente condensación simbólica, convierte un sistema basado en diferencias sexuales complementarias en otro basado en distinciones jerárquicas. Este cambio, que en principio y en términos históricos no tiene mucho que ver con la represión de la sexualidad, sino con el dominio cultural del Falo y de sus sustitutos simbóli- 
cos, y que Occidente ha experimentado desde las invasiones indoeuropeas y el desembarco de los dioses solares, abolirá las genealogías y deidades femeninas, su lengua y su particular visión del cosmos y de la naturaleza ${ }^{21}$. Si hacemos caso a Bachofen (1987: 48 y ss.), en Grecia la libertad sexual, promovida por Afrodita y más tarde recuperada por Dionisos, será domesticada en la cultura demetríaca y más tarde redefinida por el patriarcalismo. Sin embargo, la experiencia moderna de la represión sexual y del pudor que acompaña a su expresión es más reciente. Siguiendo a Elias, podemos situarlo en el comienzo de la "curva civilizatoria» que contendrá la sexualidad en la sociedad cortesana del siglo XVI (Elias, 1988: 209-220). Antes, la sexualidad era más visible, el pudor inexistente, la prostitución oficialmente influyente, el adulterio más tolerado y los niños no eran apartados de conversaciones que hoy calificaríamos de obscenas. La modernización de la sociedad y del carácter ha reprimido y ocultado la sexualidad, aumentado la distancia jerárquica entre hombres y mujeres y creado la imagen inocente y casta que, aún hoy y a pesar del psicoanálisis, mantenemos de la niñez. Pues bien, la disidencia sociocultural juvenil tiene que ver aquí tanto con el protagonismo que, vía represión, ha concedido la modernidad a la sexualidad como con la violencia cultural falocéntrica traída por los indoeuropeos.

En relación a la otra cuestión, la falta de obsesión por lo sexual, los jóvenes parecen relativizar con sus actos la sexualidad en el doble sentido de no darle más importancia que a otros fines y de expresarla, si llega el caso, espontáneamente. La desregulación moral de la sexualidad a la que se incorporan los jóvenes contemporáneos parece haber tenido lugar en dos fases desde principios de siglo. La primera, en los años veinte (Modell, 1991: 130), estructuralmente motivada por la prolongación de la escolaridad y el retraso en el acceso a las responsabilidades, tuvo que ver con la implantación del «sistema de citas», ritual que cumplió la función de permitir la satisfacción sexual sin tener que esperar al tardío matrimonio; la segunda, más conocida y de mayor alcance, por cuanto es la que comienza a atacar también el falocentrismo, tiene lugar en los años sesenta y forma parte del movimiento contracultural californiano. Según esto, los jóvenes actuales, favorecidos por el progresivo debilitamiento de la puritana moral alumbrada por la modernidad, no han hecho sino heredar, y si acaso tornar más espontáneas, las conquistas sexuales de generaciones anteriores de jóvenes. Sin embargo, tal y como se ha comprobado, la actividad juvenil en But no era del todo espontánea. No sabemos entonces a qué tipo de sociabilidad puede dar lugar la autorregulación sexual que intentan ejecutar: si a una visibilización de su práctica, si al origiasmos colectivo del que habla Maffesoli, si al hetairismo que descubriera entre los antiguos Bachofen...

${ }^{21}$ Véanse Violi (1991: 38 y ss.) y Ortiz Osés (1993: 17 y ss.). 


\section{AGON II. VIOLENCIAS INTRAESPECÍFICAS}

Sigamos con el ceremonial agon pero ahora prestando atención a las relaciones interpersonales. Según sugieren los análisis de Lorenz, la violencia intraespecífica, la que se da entre miembros de la misma especie, no sólo es muy importante entre los animales, al permitir la selección de los individuos más aptos y la óptima adaptación al medio, sino que interviene también de un modo decisivo en las relaciones humanas. Para Hacker (1973: 51-53), la agresividad humana tiene tres destinos diferentes: una parte es «donada» al Estado para que monopolice el uso de la violencia y garantice así la paz social; otra parte es sublimada y orientada hacia la cultura, dando lugar a la cortesía, el deporte, el sistema meritocrático, etc.; y un tercer montante de agresividad es reprimido por el propio sujeto. Pues bien, aunque este control de la agresividad permite una convivencia pacífica de los individuos en la sociedad, vamos a comprobar que los jóvenes de But ensayaban una paz social distinta que compaginaba el disfrute de la agresividad con el bloqueo de su contagiosa propagación.

En los meses que estuve en Pasapoga no tuve oportunidad de presenciar una sola pelea, ni siquiera un enfrentamiento verbal que me recordara a las que había observado entre los jóvenes de But. Es más, entre los varones no sólo no tenían lugar riñas o disputas, sino que el mismo trato conversacional era infrecuente. Efectivamente, absortos en la ejecución de sus rituales de seducción o atentos a cuanto sucediera en la pista, el trato interpersonal se puede decir que era inexistente. Solamente los sábados, cuando en el pasillo del piso superior, sentados en torno a la televisión por la que se retransmitía algún partido de fútbol, comentaban animosamente las jugadas e incidentes más interesantes, puede decirse que los desconocidos tratasen entre sí. Por el contrario, las mujeres, que solían venir en grupos, sí que conversaban, y animadamente, entre ellas.

Entre los jóvenes de But la violencia intraespecífica, sin llegar a ser una actividad generalizada, era al menos más frecuente que en Pasapoga. Cada semana se producía al menos una pelea. Como sucedía con el agon interespecífico de los adultos de Pasapoga, tales peleas estaban sometidas a un formalismo ritual bastante estricto que los ejecutantes solían obedecer fielmente. Debido a las características del ambiente, masificado y escasamente apto para la observación, nunca pude percibir claramente las causas por las que la violencia se desataba, pero no es arriesgado deducir que el desordenado y masivo ambiente habría podido propiciar encuentros bruscos con empujones, derrame de líquido, etc., a partir de los cuales el rito agonal comenzaba. Sobrevenido el accidente, el ritual encargado a la vez de mostrar y contener la agresividad comenzaba con una discusión. Tras un primer lance recriminatorio el aludido podía excusar su torpeza o brusquedad, acudiendo al repertorio de fórmulas que el código de los buenos modales contiene, o justificando adecuadamente la involuntariedad del desafortunado encuentro, pero también podía alimentar la 
escalada verbal. A partir de este momento, superado el umbral de la cortesía gracias al que se sostiene la paz social, los sujetos debían inscribirse en un espacio de sociabilidad próximo al de la violencia que comparte sus reglas: si seguían adelante debían cumplir la ejecución del ritual, incluso eventualmente experimentar la violencia física, y, por lo tanto, aspirar a la victoria; si, en cambio, retrocedían, saldrían automáticamente del agon como perdedores.

Ya en el ritual se producían dos cambios. Por un lado, el círculo de jóvenes próximo a los oponentes, casi todos ellos pertenecientes a los respectivos grupos de pertenencia, se incorporaba al ritual como público de primera fila que casi siempre intervenía para limar asperezas. El otro cambio tenía que ver con el endurecimiento de la confrontación verbal. El volumen de voz crecerá, el tono se hará más cínico y se producirá un fluido intercambio de insultos en el que los oponentes pondrán en cada intervención dosis, a partes iguales, de ingeniosidad y hostilidad. En la última fase el espacio lingüístico era prácticamente desbordado por el empuje de la agresividad y, en el último instante, aparecía una violencia física que no llegaba nunca a descargar. En efecto, la violenta emergencia de la agresividad en los sujetos sucederá justo en el momento en que los grupos de pertenencia se apresten a sujetar a uno o los dos oponentes tras haber intuido que el paso de la violencia verbal a la física era inminente.

Este ritual escenificado por los jóvenes de But conjuraba el riesgo de violencia recíproca, que es inmanente al orden social, pero en lugar de sublimarlo a través del trato cortés que ha instituido la modernidad, como hacían los adultos de Pasapoga, permitía que se manifestara más transparentemente, de un modo en el que la agresividad era a la vez presentada y contenida, impidiendo así su extensión por contagio. Este modo de autorregulación de la violencia ha sido observado también en el aggro o "combate ritual» de los hooligans ingleses, en el que la mayoría de sus actos "no conllevan contacto físico alguno y se limitan a gestos simbólicos e intercambios de insultos» (Harre, 1987: 65); y es formalmente idéntico también a las peleas entre animales observadas por Tinbergen (1985: 170), pues tampoco suelen acarrear derramamientos de sangre. Estas dos observaciones permiten dar ciertas pistas para evaluar la disidencia sociocultural que con este ceremonial protagonizaban los jóvenes.

La agresividad, del mismo modo que la sexualidad, ha sido objeto de una regulación cultural de la que ha resultado el tipo de individuo y el tipo de sociedad sobre el que se ha erigido la modernidad. No obstante, desde hace unas cuantas décadas la etología, emulando en parte el camino trazado antes por el psicoanálisis, ha ido más allá de los axiomas morales que justifican la autocoacción y heterorregulación de la agresividad. Además de haber mostrado, siguiendo el camino trazado por Darwin, su importancia en la selección natural y en el equilibrio entre la población y los recursos del medio que garantizan la conservación de la especie y la continuidad del ecosistema, etólogos como Lorenz han observado que la agresividad es la materia prima de un sistema económico productor de sociabilidad que se parece mucho, en cuanto a funcionamiento y resultados, al que regula la pulsión sexual. En concreto, 
como sucede con todo movimiento instintivo al que le es negado la posibilidad de descarga, la represión de la agresividad tiende a inquietar la existencia del animal y a hacerle buscar compulsivamente los estímulos que la desencadenen, forzando a la postre una descarga más explosiva (Lorenz, 1972: 64). Pues bien, la cultura ha pulido y seleccionado "rituales filogenéticos» (Lorenz, 1972: 73; Hacker, 1973: 97-98), costumbres, instituciones y ritos que han permitido a la vez la descarga de la pulsión en objetos sustitutivos y el aprovechamiento de su energía para la producción de sociabilidad: así ha sucedido, en general, con la comunicación y, en particular, con los buenos modales, la amistad, la competitividad meritocrática, el deporte, etc. Sin embargo, los cambios sociales más importantes han sido causados por la monopolización del uso de la violencia (Elias, 1988: 449 y ss.), pues se construyó un orden social pacificado, se distinguió entre violencias legítimas e ilegítimas y se instituyó un carácter producido en gran medida por la represión de la agresividad. Antes de la «sociedad cortesana» de los siglos XVI y XVII, la circulación libre de violencia había encumbrado figuras, como la del caballero, que vivían obteniendo placer del ejercicio de la agresividad y que eran abiertamente admiradas por todos. Según ha observado Elias, «la alegría producida por la tortura y el asesinato de los otros era muy grande»; es más, "era una alegría socialmente permitida» (Elias, 1988: 233). Posteriormente, la heterorregulación de la violencia y la contención general de los instintos instauraron un nuevo tipo de subjetividad sostenida por los buenos modales y la cortesía. Sin embargo, esta pacificación de la existencia lograda con el monopolio de la violencia y la represión y sublimación de la agresividad tuvo también sus efectos perversos

En primer lugar, el «proceso de civilización» necesitó compensar la falta de experiencia de la agresividad con el deporte y la exposición a violencias relatadas o imaginarias (Elias, 1988: 240; Hacker, 1973: 482; Imbert, 1992). En segundo lugar, el tipo de paz social construido en la Modernidad ha hecho que, como sucede entre los animales, la represión de la agresividad haga que se descargue a destiempo y más compulsivamente. $\mathrm{Y}$, por último, la domesticación generalizada de la agresividad, a pesar de lograr hacer desaparecer los miedos exteriorizados, o quizá por eso mismo, fomentó la aparición de otros interiores que han generado una permanente sensación de inseguridad (Elias, 1988: 527). En opinión de Chesnais (1981: 432), es como si «en plena época de paz las sociedades jugaran a hacerse miedo", "esta vez contra un enemigo interior», pues "toda paz prolongada parece entrañar una lenta desagregación del contrato social, una erosión progresiva del consenso». Es por esto que, "para renacer, el cuerpo social tiene necesidad de grandes misiones salvadoras, de cruzadas contra el mal».

Los jóvenes de But no aceptaban la paz social moderna ni el trato cortés que la sostiene. Preferían más bien regular la agresividad a través del aggro. De este modo conjuraban igualmente el riesgo de violencia recíproca que permanentemente acecha en lo social, pero transgredían el régimen de monopolio al que está legalmente restringido su uso. Así, pues, la agresividad juvenil era 
sometida a una ritualización simbólica bastante estricta que es un modo distinto de conjurar el riesgo de violencia recíproca. Sólo por esto ya se puede hablar de una disidencia cultural respecto a la paz social instituida en la modernidad. Pero es que, además, con el aggro el joven era capaz también de experimentar un placer vetado a quienes obedecen los códigos del trato cortés, ya que tienen acceso a un modo de expresión y a una fuente de poder que los adultos, perfectamente insertados moral y culturalmente en la sociedad instituida, desconocen y temen.

\section{AGON III. LOS VALORES DE LOS OBJETOS}

Además de la violencia interespecífica sexual y la intraespecífica entre iguales, en el agon lúdico de los jóvenes de But pude observar otra manifestación social de la agresividad, el vandalismo. A diferencia de los otros dos tipos de violencia, ésta sólo se da en las sociedades humanas. La razón es que esta agresividad tiene por objeto las cosas y sólo el hombre ha sido capaz de rodearse de un entorno adecuado para su descarga. Desde los inicios de la modernidad, y más exactamente desde la revolución industrial, objetos de todo tipo producidos a gran escala proliferan por doquier regulando de distintos modos gran parte de las interacciones. Esta cohabitación con los objetos ha inducido hábitos de trato cordial y respeto que, como veremos, obedecían a la perfección los adultos de Pasapoga. Por contra, los jóvenes de But parecían socavar también este otro pilar de las sociedades modernas descargando su agresividad contra ellas.

Los adultos que acudían a Pasapoga mostraban una escasa predisposición para practicar esta violencia. Su trato con los objetos, como sucedía en las relaciones interpersonales, era exquisito. No sólo no aparentaban sublimar ninguna agresividad, sino que incluso ayudaban al personal en el mantenimiento del orden de la sala y en la reparación de cualquier desperfecto de su mobiliario. Así, era normal que solicitaran a los camareros la limpeza de las mesas o las sillas que ocasionalmente se encontraban sucias, e igualmente que reclamaran el servicio de la señora encargada de la limpieza para recoger los restos de algún vaso roto. Incluso, ante otros desperfectos de mayor envergadura solicitaban la presencia del encargado del mantenimiento, al que solían ayudar en su trabajo. Había, pues, una ordenada convivencia entre sujetos y objetos gracias a que los adultos cuidaban y respetaban el mobiliario de la sala. Ahora bien, ¿cómo interpretar ese orden?, ¿cuál es su sentido? Da la impresión de que los objetos de Pasapoga tenían para su público un valor de cambio funcional que remitía no a los sujetos en virtud de su uso, sino al propio sistema de los objetos a través de una estructura de equivalencias. En este sentido, el respeto y el buen trato dirigido por los sujetos a los objetos afirmaba la alienación del hombre respecto a sus productos.

En cambio, el trato de los jóvenes de But con los objetos no era tan amis- 
toso. Sabedor de la capacidad destructiva de los jóvenes, el maitre tenía por costumbre ordenar la retirada de algunas mesas, sillas y ceniceros que luego por la noche (con otra clase de público) eran devueltos a su lugar habitual. El ambiente presentado a los jóvenes era, por lo tanto, más austero y menos suntuoso que el ofrecido por Pasapoga a los adultos. En este contexto, el mal trato que los jóvenes dispensaban a los objetos no desentonaba en absoluto. Ya desde el comienzo, los jóvenes que decidían sentarse en los sillones que rodeaban la pista lo hacían apoyando sus pies en las mesas o en los taburetes. Los camareros estábamos obligados a impedir este comportamiento, pero apenas nos dábamos la vuelta, después de haber recriminado a los infractores, la cómoda e incorrecta postura volvía a practicarse. Sin embargo, la mayor desatención a las cosas y al mobiliario venía después, cuando el alcohol y la música calentaban los ánimos. Con el anonimato que proporcionaban los juegos de luces, la rotura deliberada de vasos en la pista era imposible de controlar. El vandalismo se cebaba también con otro mobiliario de difícil vigilancia, el de los servicios, entre el que espejos, secadores y retretes eran los objetos preferidos. Cuando a media hora del final las luces alumbraban ya la sala casi perfectamente, el ambiente era desolador. Las mesas llenas de líquido (en parte ya adherido a la superficie), el suelo pegajoso, cristales rotos y vasos vacíos en casi todos los rincones, sillones y taburetes deteriorados, etc. El cuadro lo completaban unos jóvenes que no desentonaban en absoluto con el ambiente. ¿Cuál es el contenido de la disidencia sociocultural juvenil en este caso?

Si en la premodernidad la producción de objetos se realizaba teniendo principalmente en cuenta su valor de uso, definido en términos de utilidad para satisfacer necesidades, en la modernidad capitalista adquiere importancia el valor de cambio, pues un objeto es producido principalmente para ser vendido, siendo su utilidad un asunto menor. En esta fase, valor de cambio y valor de uso se corresponden con los términos significante y significado del signo tal como fue definido por Saussure y redefinido por Lacan. En efecto, del mismo modo que el significado no es sino el imaginario respecto al significante, el valor de uso no es sino la coartada ideológica del valor de cambio (Núñez García, 1988: 255; Ibáñez, 1994: 235). Pues bien, durante este siglo se ha producido un hecho que, según Baudrillard (1988: 59 y 71), ha permitido la definitiva autonomización del sistema de los objetos: la sustitución del valor de uso por la funcionalidad - la «capacidad que tienen [los objetos] de integrarse en un conjunto»-, lo que ha jugado en favor de la independencia definitiva de los objetos. Por eso, los objetos forman hoy un sistema autónomo estructurado no según su adecuación al hombre en términos de satisfacción de necesidades, sino de acoplamiento funcional. Sólo funcionan como signos, y su reino se separa cada vez más del de los hombres.

Según esto, los adultos de Pasapoga no hacen sino aceptar esa exterioridad de los objetos y resultar, por lo tanto, alienados. El buen trato con ellos, el grado cero de utilidad de gran parte del mobiliario, el respeto de lo suntuoso y la aceptación del exquisito servicio como mediación muestran casi más una 
subsunción de los sujetos en el sistema de los objetos que una relación en términos de igualdad entre los dos órdenes. En cambio, la actitud de los jóvenes ante el sistema de los objetos es bien distinta. El uso perverso inventa nuevos acoplamientos sujeto-objeto que impiden la definitiva exteriorización de los productos de sus productores. El vandalismo, más drástico, impide la alienación destruyendo el objeto. Son las vías débil y fuerte por las que el sujeto retorna frente a los objetos a la posición de amo. Pero hay que verlas por partes. Los usos perversos son producidos en el «espacio transicional» de Winnicott (1993: 61 y ss.), el que media entre el sujeto y el mundo, dando lugar a una relación con los objetos muy singular. Si hacemos caso a Agambern (1995: 23-112), parece ser la misma relación a la que se refirieron los filósofos medievales cuando analizaron el mal melancólico, o Freud mismo cuando atendió a la función libidinal del fetiche, o incluso Marx cuando advirtió las propiedades místicas de las mercancías. En todos los casos sucede que el sujeto produce inevitablemente un objeto fantasmático con significados singulares que con el tiempo se le irá de las manos y le alienará. Pero antes de que esa alienación tenga lugar, como sucede con el juguete en manos del niño, el objeto es utilizado, recreado, investido de cierto valor por el sujeto.

Por lo que respecta al vandalismo, Lipovetsky (1987) ha dicho de él que responde al proceso hard de acción radical que en la postmodernidad acompaña al proceso cool de retirada del ser. En efecto, cuando el código que distribuye usos deja de ser aceptado y lo real pierde su sentido convencional, la degradación vandálica anula el respeto por las cosas y proporciona a los sujetos sensaciones inmediatas de otro orden. Más allá de la retirada del ser podemos entender, siguiendo a Bataille (1987) o Girard (1983), que el vandalismo juvenil recupera para los objetos su ancestral y sagrado «valor» sacrificial. En efecto, la esencia de la destrucción es un "consumir sin beneficio lo que hubiera permanecido encadenado al mundo de las obras útiles» (Bataille, 1987: 94). Pero, además, el vandalismo es también el modo como se expresa en el orden de los objetos algo parecido a lo que Freud denominara, en el orden libidinal, «instinto de muerte» (Freud, 1993: 272-333), pues la destrucción hace huir del mundo real poblado por cosas distintas y útiles y retornar a la indistinción y gratuidad de la naturaleza.

Según lo expuesto, es obvio que el trato de los adultos con los objetos cuando se divertían en Pasapoga mantenía el orden moderno instituido, pues o reproducían el acoplamiento funcional de los objetos de la sala, con lo que se alienaban, o los usaban convencionalmente para satisfacer determinadas necesidades, con lo que se integraban en él. Entre esas dos posiciones oscilaba el agon de los adultos respecto a los objetos. Por su parte, los jóvenes de But se situaban en la socialidad pues, inventando usos inéditos difícilmente codificables, disipaban las convenciones relativas al trato sujeto-objeto para satisfacer necesidades, lo que daba un protagonismo pleno al valor de uso. Y con el «valor» sacrificial que activaba el vandalismo se destruía la realidad objetal misma y se cuestionaba el orden de la producción, lo que impedía la existencia 
de cualquier valor. De los dos modos, el sujeto volvía a su posición de amo frente a los objetos

\section{ILINX. EL CONSUMO DE DROGAS}

El término griego ilinx deriva de ilingos, que suele traducirse como "vértigo» (Caillois, 1967: 71). En tanto que componente lúdico tiene que ver, según Caillois, con la tendencia a "destruir por un instante la estabilidad de la percepción y de infringir a la conciencia lúdica una salida de pánico voluptuoso» (p. 67). Suele alcanzarse este fin placentero mediante la práctica de deportes que llevan incorporado cierto riesgo como son el motociclismo, el esquí, el alpinismo, etc. Sin embargo, aquí se va a tener en cuenta el vértigo que experimentaban los jóvenes de But y los adultos de Pasapoga con la ingestión de drogas. Aunque el placer obtenido de este modo no tiene mucho que ver con el "pánico voluptuoso" producido con la práctica de deportes arriesgados, en los dos casos se resuelve de manera idéntica: con la ruptura de la estabilidad perceptiva. En efecto, según ha señalado Freud (1982: 43), «bajo el influjo del alcohol el adulto se convierte nuevamente en niño al que proporciona placer la libre disposición del curso de sus pensamientos sin observación de la coerción lógica».

El consumo de alcohol entre los adultos de Pasapoga estaba determinado por una norma paradójica de difícil obediencia, pues a la vez que incitaba a cierta alteración del estado de conciencia ordinario se prohibía que esa alteración fuera muy acentuada. En efecto, desde el tipo de orden que es inherente a la socialidad, Pasapoga no hacía sino poner a disposición del cliente los medios legalmente aceptados para que alterara su conciencia ordinaria consumiendo alcohol, pero, a la vez, el orden de la sociedad también hacía llegar a la sala la obligación de impedir alteraciones excesivas de la misma. El público se veía así sometido a una típica situación de doble vínculo (Bateson, 1991: 236-241). Pues bien, según las distintas respuestas dadas a esta paradójica norma, pude distinguir distintas modalidades de consumo de alcohol. En primer lugar, una minoritaria transgresión por exceso entre aquellos que alcanzaban grados no permitidos de embriaguez con máxima alteración de la conciencia. Tan minoritaria fue esta transgresión que sólo pude presenciar un ejemplo. En segundo lugar, también era posible desobedecer la contradictoria norma por defecto, como hacían los abstemios. Cabe ubicar aquí a un importante contingente de clientes que acudían los fines de semana con la intención de buscar pareja, finalidad a la que dedicaban todas sus energías y que hacían incompatible con cualquier otra actividad lúdica. Y, en tercer lugar, era posible una obediencia estricta del contradictorio imperativo que los adultos lograban alterando su conciencia pero manteniendo hegemónico su yo.

Sin embargo, en este tercer y mayoritario grupo podemos distinguir dos subgrupos. El formado por quienes tomaban la primera consumición a que 
daba derecho el ticket de entrada (quizá por compromiso, una o dos más), pero no aparentaban buscar la alteración de la conciencia, simplemente adecuarse al tipo de comportamiento habitual en la sala; y el de quienes bebían porque les gustaba. Sin embargo, aún pude hilar más fino en la clasificación y distinguir en este segundo subgrupo a quienes asociaban el consumo de alcohol a otros divertimentos, como el ligue o el baile, y quienes bebían de un modo absolutamente expresivo. Los primeros estaban bien representados por los que se apostaban en la barra y cuando el ambiente se distendía ejecutaban sus recorridos para encontrar candidatas con las que practicar el ceremonial de seducción. Lo revelador de este grupo era que, a pesar de su aspecto "normal», si había oportunidad de acercarse a ellos e intercambiar algunas palabras, lo que sucedía cuando pedían otra copa, uno se daba cuenta de lo ebrios que estaban. Queda, por último, el subgrupo de quienes beben de un modo absolutamente expresivo, sin vincularlo a ningún otro divertimento. Como mejores representantes de esta clase de público estaba un grupo de bebedores de whisky, habituales en la sala y espléndidos con las propinas, que no abandonaban su sitio más que para ir al servicio. Solían consumir entre 5 y 8 copas de este licor, combinadas con agua o refrescos, y de vez en cuando se entretenían conversando entre ellos o con los camareros

Además de la clasificación anterior, realicé otra prestando atención a lo que bebían. Y lo que concluí es que mostraban una gran adhesión al abanico internacional de combinados que comenzó a extenderse a mediados de los setenta y que los adultos indistinguían con el término "cubalibre». También exhibían una casi enfermiza fidelidad a la composición de la consumición que habitualmente ingerían, a las marcas de licores o refrescos y, en el caso de las mujeres, a los detalles y ornamentos con los que embellecíamos los cocktails.

Pasando a los jóvenes, conviene comenzar haciendo referencia a dos estudios. El primero, sobre los hábitos en el consumo de alcohol de los epañoles, fue encargado en 1973 por la Comisión Interministerial sobre el Alcoholismo y el Tráfico de Estupefacientes. En él se constató la existencia de una pauta de cosumo de alcohol clásica o tradicional respetada por adultos y jóvenes (Alvira, 1986). El modelo describía un consumo preferentemente de vino que, con criterios instrumentales, se efectuaba en las comidas. No obstante, a mediados de los ochenta este modelo fue sustituido por otro distinto. La cerveza, acompañada en un segundo plano por el licor, suplantó la tradicional hegemonía del vino. Se comenzó a beber menos en casa durante las comidas y más fuera, por la tarde o noche de los fines de semana. Y aunque se mantuvo el consumo de alcohol puro per cápita en torno a los 12,1 litros por año, apareció el bebedor exclusivo o casi exclusivo de fin de semana, con el que adquirió importancia el consumo expresivo, y aumentó significativamente el número de borracheras. El segundo estudio, esta vez cualitativo, lo encargó en 1982 la Dirección General de la Salud Pública del Ministerio de Sanidad y se basó en una muestra de jóvenes de entre 12 y 29 años que mostraban dos llamativas singularidades, luego confirmadas por estudios posteriores (Alvira, 1986: 112; Sanidad y 
Consumo, 1995: 21-30): que el valor expresivo del alcohol era cada vez más importante y que el inicio en el consumo se efectuaba a menor edad, fuera de casa, con los amigos, y se veía favorecido por una disponibilidad de tiempo, dinero y locales mayor que en otro tiempo.

Centrándonos ya en los jóvenes de But hay que comenzar constatando que, a diferencia de los adultos de Pasapoga, no tenía tanta importancia entre ellos la obediencia de esa norma paradójica que promueve la autoalteración de la conciencia con el consumo de alcohol pero prohíbe llegar a estados de ebriedad. Corroborando el interés por el consumo expresivo y el incremento del número de borracheras que desvelan los estudios, la transgresión por exceso era bastante más frecuente y la sobriedad o transgresión por defecto prácticamente inexistente. Había, pues, en el joven público de But una mayor permisividad para con la desterritorialización de la subjetividad y, por lo tanto, también una menor disciplina yoica.

No obstante, el alcance de la disidencia sociocultural juvenil en relación al ilinx era de mayor alcance si, además de al cuánto son capaces de autoalterarse con alcohol la conciencia, atendemos al cómo y al con qué lo consiguen. En general, tanto por el interés en proporcionarse rápidos y contundentes estados de euforia como por la escasez de dinero, los jóvenes suelen consumir, además de las bebidas tradicionales, combinados explosivos de efectos inmediatos que se alejan mucho del abanico de «cubalibres» que han conseguido estabilizar los adultos. En el consumo de esos combinados tiene una importancia fundamental el valor expresivo, pues lo que se buscan son sensaciones fuertes inmediatas, pero también permiten estar juntos pues, aunque el formato sea en muchos casos (no todos) individualizado, las bebidas se ingieren siempre en compañía de otros. Este comportamiento pude observarlo en uno de los bares cercanos a $B u t$ en el que los jóvenes quedaban para entrar juntos en la discoteca. Aunque dentro de But no se servían brebajes tan explosivos, el abanico de combinados construido por los jóvenes clientes lograba ser más extenso y abierto que el de los adultos. Además de los «cubalibres», whiskies y cervezas, se consumían combinados más extraños con una graduación similar pero estéticamente distintos. En efecto, sobre la base de un licor cualquiera (vodka, ginebra, ron, etc.) se añadía lima, kiwi o maracuyá; también se formaban combinados exóticos con curação azul y Seven Up, y algunos se atrevían a inventar combinaciones mezclando más jarabes o refrescos con los licores tradicionales. Quienes más se aventuraban con estos combinados tan exóticos eran las chicas, y sobre todo las más jóvenes. Este gusto por la estética del formato, tan abierto a la novedad, del mismo modo que la composición y calidad del combinado que observé entre los adultos, permite dar forma cultural al ilinx. Sin embargo, mientras los códigos de los clientes de Pasapoga eran fuertes, estables y cerrados, los de los jóvenes de But eran débiles, dinámicos y abiertos, por lo que permitían una mayor autonomía creativa del bebedor.

Pero los jóvenes no sólo consumían alcohol para alterar su yo, también solían consumir drogas ilegales. Como ha sucedido con el consumo de alcohol, 
el de las drogas ilegales ha experimentado una mutación importante con los jóvenes de las últimas generaciones. En un primer momento, desde los años cuarenta hasta finales de los setenta, se daba un consumo casi exclusivo primero de grifa y después de hachís en círculos reducidos y marginales, como eran el de los «grifotas» barceloneses o el del ambiente «cheli» madrileño, a los que al final se unieron los "pasotas", militares de reemplazo y algunos "progres" (Rodríguez González, 1989; Oriol Romaní, 1989: 90-93; Lamo de Espinosa, 1993: 97). Sin embargo, desde finales de los setenta, siguiendo la estela del cambio experimentado por el consumo de alcohol, el de hachís se extendió entre los jóvenes y, de un modo improvisado, comenzaron a consumirse drogas nuevas como las anfetaminas, la heroína, la cocaína, el speed, el LSD. Hay entonces, como en el alcohol, dos pautas de consumo de drogas ilegales que se suceden en el tiempo: una primera tradicional y restringida en torno al hachís, y otra posterior amplia y abierta que involucra más sustancias. En el caso de los jóvenes de But, resultó difícil recabar información sobre el consumo de drogas ilegales, pues la dirección de la sala lo prohibía y, por mi condición de camarero, no resultaba ser la persona más adecuada para preguntar o poder observar este tipo de conductas. No obstante, gracias a mi propia observación y a la información proporcionada por mis compañeros, pude concluir que el abanico de drogas ilegales consumidas debía estar formado, además de por el hachís, cuyo consumo era bien visible (y «tolerado»), por las anfetaminas, el speed, la cocaína y el «éxtasis».

Antes de pasar a evaluar el alcance de la disidencia sociocultural juvenil en relación al ilinx, convendrá que atendamos al discurso sobre esas drogas producido por la sociedad, descubramos la estructura profunda de la moral prohibicionista que lo sostiene, así como el tipo de legalidad que de ello resulta, y señalemos cuál es la base sociocultural afectada por ese consumo. En este sentido conviene comenzar constatando que en todas las grandes culturas, incluida la occidental, encontramos tanto el consumo de sustancias que permiten la autoalteración de la conciencia como actitudes prohibicionistas. No obtante, el antecedente directo de la actitud que nos afecta contemporáneamente a los occidentales data de finales del siglo XIX y en ella confluyen intereses del estamento médico, de la industria química y de la profesión farmacéutica, una moral puritana profundamente religiosa e igualmente el rechazo de minorías, inmigrantes y otros sectores marginales de la sociedad. En 1900 este complejo de intereses ya ha logrado, según observa Escohotado (1990, 2: 225), formular en Estados Unidos la máxima que inspirará la penalización: «ilegalizar todo apetito antinatural, entendiendo como tal la ebriedad en cualquiera de sus formas». Con esta formulación, los prohibicionistas no hacen sino expresar moralmente el interés de la modernidad por imponer una subjetividad dominada por la Razón. Sin embargo, en esa actitud concurren bastantes más circustancias. Las primeras drogas a las que se referirán los prohibicionistas son el opio, la cocaína y la marihuana, que forman parte de las subculturas negra, mexicana y china de Estados Unidos, mientras que la actitud será mucho más 
permisiva respecto al té, el café, el tabaco y el alcohol, drogas todas ellas habituales entre las mayorías de origen europeo. En último término, la criminalización de esas drogas apunta realmente a sus consumidores y tiene como función el negar su identidad (Lamo de Espinosa, 1993: 32-36; Becker, 1985; Sansone, 1988). Pues bien, por lo que respecta a los jóvenes lo fundamental es también que consumen drogas distintas y que «en tal diferencia se apoyan los adultos para exagerar ciertos hechos y quizás así justificar el uso de sus propias drogas» (Comas, 1985: 113). Si tenemos en cuenta la conflictiva relación que vincula a jóvenes y adultos y que son estos últimos quienes habitan centralmente la sociedad en la que están obligados a insertarse aquéllos, resulta evidente que el llamado "abuso de drogas» es uno más de los ceremoniales que el joven usa para afirmar su identidad y que la "guerra contra las drogas» es la respuesta que dan los adultos para imponer su sistema de valores y hacer valer su posición dominante (Szasz, 1990: 277).

La moral y la ley aplicadas para estigmatizar y penalizar el consumo de las drogas ilegales son, según lo expuesto, expresión de ciertas relaciones de poder inscritas en el orden de la sociedad que pivotan en torno al enfrentamiento entre jóvenes y adultos, grupos étnicos dominantes y marginales o prácticas políticas oficiales y subversivas. Sin embargo, el problema de las drogas, ya en general, tiene que ver también con un asunto de mayor alcance como es la oposición entre la afirmación y el cuestionamiento del tipo de subjetividad instituida y apuntalada en la modernidad. Efectivamente, si un pilar sociocultural está afectado por esos enfrentamientos es el modelo de subjetividad exclusivamente racional, el yo, propuesto por la mentalidad cartesiana que, además de sentar los cimientos de la modernidad, permitió definir la locura, la infancia, la brujería y la ebriedad como desviaciones sociales (Varela y Álvarez Uría, 1986: 25 y 36). Conviene recordar que, aunque todas las culturas han debido instituir su propio modelo de subjetividad otorgando importancia al yo, pocas como la modernidad han efectuado la operación tan drásticamente (Fericgla, 1989). Todos esos consumos transportan, además, a estados subjetivos habituales en el infans, y tienen ciertas similitudes con el pathos esquizofrénico. Pero es que, además, como ha observado Maffesoli (1985), el orgiasmos asociado al consumo de drogas permite reforzar la solidaridad orgánica de la socialidad, "lograr que todos seamos uno y que cada uno seamos todos». Es por esto que el consumo de dichas sustancias permite una regresión de la subjetividad a estados filogenéticos y ontogenéticos primarios, por lo que supone una anamnesis o retorno de lo expulsado por el yo y el orden social que lo encumbró. Y es que, como han observado Deleuze y Guattari (1988: 285), las drogas (sobre todo las llamadas «duras») proporcionan al inconsciente molecular el plano de inmanencia que el psicoanálisis no ha cesado de fallar. De ahí que la condena moral encargada de proporcionar representaciones sustitutivas al consumo de drogas y la estrategia represora que la culmina no sólo afecte a los jóvenes, a grupos étnicos o a la subversión política. Forma parte de una estrategia de vigilancia, represión y encierro de estados de conciencia no res- 
ponsables o irracionales que ha afectado también, aunque de modos distintos, a otras conductas calificadas por la moral y las ciencias sociales como desviadas.

\section{MIMICRY. LAS COMPOSICIONES VESTIMENTARIAS}

Para finalizar, pasemos a ver las composiciones vestimentarias con las que los adultos y los jóvenes se presentaban en Pasapoga y But. Entiendo que el vestuario es el material con el que trabajan los sujetos para expresar simbólicamente algunas de las más importantes determinaciones que atraviesan lo social. Pues bien, con mi observación intenté averiguar si los vestuarios de los jóvenes de But y de los adultos de Pasapoga remitían a las determinaciones más duras de la sociedad, como son las distinciones en términos de clase, género y edad, o, por el contrario, apuntaban a ese territorio incógnito en el que suceden cosas menos previsibles y que Maffesoli denomina socialidad.

El público adulto de Pasapoga parecía utilizar correctamente el vestuario, en el sentido de que vestían lo que se debe vestir y aparentaban lo que se debe aparentar según las normas que son dominantes en la sociedad en la última fase de la modernidad. Tanto los varones como las mujeres se singularizaban como adultos, por cuanto muy pocos llevaban prendas popularizadas por los jóvenes desde hace unas cuantas décadas como son los jeans, la ropa deportiva, las camisetas, etc., y además tampoco exhibían las que les son propias con el desenfado, la innovación y el desaliño de que hacen gala ciertos jóvenes cuando les toca a ellos ponérselas. Los varones respondían al mandato de mostrar o simular estar en posesión de un estatus de clase media o media-alta, vistiendo el uniforme que desde hace al menos dos siglos y con mínimas variaciones la sociedad ha instituido y que consta de pantalón de vestir, camisa, a veces también chaleco, chaqueta, cinturón, corbata, zapatos y calcetines oscuros, además de pelo corto y afeitado reciente. Sobre esta base vestimentaria de obligado uso los varones podrán tener un limitado margen para manipular algunos aspectos de esas prendas, como puedan ser los colores, las formas y los tejidos, pero siempre haciendo prevalecer una imagen austera, sin barroquismos, y preferiblemente oscura. Otros accesorios del vestuario, como son los gemelos, el reloj, los anillos, el alfiler para sujetar la corbata, etc., eran opcionales y, al margen de su utilidad o practicidad, parecían servir más para subrayar o aumentar el estatus que para dar rienda suelta a la propia expresividad. Este traje masculino desciende del que comenzó a popularizarse entre 1770 y 1780 influido por la moda inglesa. No obstante, será el austero traje burgués del siglo XIX, del que ya directamente desciende el nuestro, el que con ayuda de la masiva industria pret-à-porter logró imponerse en toda Europa, apropiándoselo incluso la clase obrera (que lo vestía los días festivos) y, en general, las populares (que abandonaron así los trajes regionales) (Deslandres, 1987: 159).

Por lo que respecta a las mujeres, la determinación genérica a la que debían adecuarse era la de vestir también con cierta etiqueta, distinguirse tanto de los 
varones como de la clase de edad juvenil, pero sobre todo la de resultar atractivas, asunto éste que, como se verá, complementa la ostentación de estatus efectuada por los varones. El vestuario más habitual del público femenino de Pasapoga puede decirse que estaba compuesto de blusa, falda, zapatos de tacón alto, y medias, además de maquillaje en el rostro y cabello (nunca corto y siempre voluminoso) esmeradamente peinado. Se trata de un uniforme casi igual de universal que el de los varones pero que admitía una capacidad de manipulación en cuanto a formas y colores muy superior. Para mostrarse atractivas, las mujeres contaban con una prenda típicamente femenina, especialmente útil para este menester, la falda, cuya función no es tanto la de ocultar el sexo o las piernas, obedeciendo así a la moral instituida, como la de "atraer la atención hacia lo que anida en el interior de su abertura» (Gil Calvo, 1991: 112). Sin embargo, según nos descubren los historiadores de la moda, esa función es reciente (Toussaint-Samat, 1994: 108-144). En el siglo XV la falda era la única prenda que los hombres y mujeres llevaban por encima, pero un siglo más tarde entre los varones sólo la vestirán clérigos, magistrados y profesores de universidad, ya que para el resto se había acortado mucho y cubrían su función los leotardos. Más tarde, por lo que respecta a las mujeres, la contrarreforma vestimentaria del siglo XVI paralizó el cuerpo femenino con el verdugado y el miriñaque, tal como ha quedado plasmado en algunos sarcásticos sonetos de Beeher (Luján, 1996: 69-73). Sólo a partir de 1891 las mujeres francesas podrán volver a sentarse sin problemas y volver a lucir la línea sinuosa. Pero será con la "alta costura», el acortamiento de las faldas y el cambio de concepto respecto a la ropa interior como las mujeres lograrán liberarse definitivamente de los cuerpos emballenados, lo que les permitirá resexualizar su ideal de belleza e independizarse progresivamente cada vez más de los dictados de la moral.

Otra de las prendas emblemáticas de las mujeres y con una función similar, aunque no tan explícitamente sexual, era el zapato de tacón alto, que cumple la función de enderezar el tronco y reforzar las curvas cóncavas y convexas que suben desde el empeine, pasando por la fetichizada pantorrilla, hasta el muslo (Gil Calvo, 1991: 110). En contigüidad metonímica con los zapatos de tacón alto y la falda estaban las medias, que, como segunda piel que son, se encargan de ocultar la primera para borrar algunas de sus imperfecciones naturales. Respecto a los accesorios, ornamentos tales como pulseras, collares, anillos y pendientes no parecían reforzar expresivamente la función erótica del vestuario y sí, en cambio, el estatus o un ideal de belleza de otro tipo. Las mujeres que a primera vista más parecían querer alcanzar con sus ornamentos esos fines eran las más mayores. Otros accesorios utilizados son el maquillaje y el peinado.

Parece, pues, que tenemos un ideal vestimentario femenino que remite a un concepto de belleza complejo pues, aunque tiene que ver principalmente con la atracción sexual que es capaz de despertar en el varón, también intenta permitir componer imágenes juveniles. Así, pues, si el varón tiene la fácil misión de borrar su posible baja extracción social y exhibir o simular pertenecer a la parte media o alta de la estructura social, la mujer parece que está obli- 
gada a algo mucho más difícil: borrar las marcas que imprime sobre su cuerpo el paso del tiempo y mostrarse joven y sexualmente atractiva.

Entre los jóvenes de But el respeto de las normas vestimentarias, y del gusto estético a él asociado, que ha instuido la sociedad durante la modernidad no es tan respetado como entre los adultos de Pasapoga. Con su vestir, estos jóvenes activan determinaciones sociales de otro orden. Comenzando por el dimorfismo sexual, tan unánimemente respetado por los adultos de Pasapoga, nos encontramos con que la mayoría del público de But lo transgrede. En efecto, el que prendas típicas de la estética masculina, como los pantalones, fueran apropiadas por las féminas y el que detalles expresivos de la femenina, como el pelo largo o los pendientes, fueran apropiados por los varones, era algo habitual entre el público mayoritario de But. En cuanto al dimorfismo de edad, el grupo mayoritario de jóvenes lo respetaba, pero esto no debe extrañar. A diferencia de lo que sucede con el dimorfismo sexual, que comienza a desarrollarse al final de la Edad Media y que desde entonces es subrayado de diferentes modos hasta el actual ocaso de la modernidad, en que vuelve de nuevo a difuminarse, el de edad surge en este siglo y no sólo se mantiene, sino que, dado el éxito que también tiene entre los adultos, los jóvenes deben esforzarse en la producción de looks siempre nuevos para mantener la diferencia.

Pero la singularización más notable de la estética juvenil viene dada por el hecho de que no remite a la sociedad, sino a la socialidad, y parece tener como misión el permitir a las tribus juveniles diferenciarse entre sí, pero no de un modo jerárquico (como hace, por ejemplo, el ideal estético masculino) sino horizontalmente, pues lo que importa no es tanto el ser más que otro como distinguirse de él. Para lograrlo, las chicas llevaban la gran mayoría bodies de color claro muy ceñido al cuerpo con cuello redondo amplio, jeans de pierna ancha sujetados con un cinturón oscuro y también ancho justo a la altura de la cintura, zapatos de suela gruesa, pelo largo, rimmel en los ojos y pocas joyas o baratijas (sólo los obligados pendientes y algún anillo o pulsera, pero ningún collar). Algunas de ellas preferían vestir ajustados tops también de color claro que en algún caso dejaban al descubierto los hombros y el vientre, o pantalones con el final de las piernas sin rematar (deshilachados), o hebillas llamativas en los cinturones, o suelas más gruesas para sus zapatos, o los labios pintados con carmín. Tanto el uniforme general como sus variantes parecían dejar de lado el sexualizado ideal estético de las féminas adultas, tampoco tenían la función de subrayar el dimorfismo sexual; pero, en cambio, sí que parece lograrse, al menos el sentido común así me lo indicaba, un reforzamiento del dimorfismo de edad, pues el aspecto de las chicas resultaba más jovial. Ahora bien, el modo como logran singularizarse frente a los adultos estas chicas, aun siendo original, entronca con una ancestral tradición. Alguna pista sobre esto nos la proporciona la historia de los jeans y del body.

Respecto a los jeans (Toussaint-Samat, 1994: 173-181), parece que fue un sastre bávaro de origen judío, Oscar Levi-Strauss, el que tuvo la idea, allá por 1853, de confeccionar con una tela de algodón de su tierra natal unos resis- 
tentes pantalones para los buscadores de oro californianos. Por otro lado, a un sastre letón llamado Jacob W. Davis se le había ocurrido reforzar las costuras de los bolsillos con remaches. En 1873, el ya millonario Levi-Strauss obtuvo la patente de los remaches y contrató a Davis. Como es de sobra conocido, más tarde fue usada y divulgada masivamente por los jóvenes de los sesenta y desde entonces se han incorporado regular o esporádicamente al vestuario de los dos géneros y todas las edades. Aunque siendo de más corta duración, este trayecto histórico de los jeans no es muy diferente del de los pantalones, la falda o la camisa, pues en todos los casos nos encontramos con un origen humilde, popular. Lo importante es que su puesta en circulación masiva fue efectuada por los jóvenes de los sesenta, que hoy esta prenda ha sido apropiada por los adultos, y que este mecanismo de invención juvenil y de apropiación adulta marca los inicios de la moda genuinamente juvenil y de la lucha de esta clase de edad por singularizarse ${ }^{22}$. En cuanto al $b o d y$, se trata de una prenda que singularizaba a estas chicas frente a otras y que tiene una historia mucho más corta. Esta prenda es una más, probablemente la última junto con las mallas y los coullottes, de las que desde los años setenta los jóvenes comenzaron a tomar prestadas del vestuario deportivo y que posteriormente, por divulgación, también han pasado a formar parte del vestuario adulto informal (Yonnet, 1988: 264).

Estos dos apuntes acerca de los orígenes de las prendas utilizadas por las chicas de But vienen a mostrar que, desde hace unas cuantas generaciones, los jóvenes están efectuando un intenso trabajo de bricolage, análogo al efectuado antaño por las clases populares con las prendas que hoy son emblemáticas de los adultos. En este sentido, bien se podría decir que el hacer popular de antaño ve continuado su trabajo hoy con los jóvenes ya que, con una facilidad parecida, han logrado apropiarse de prendas tan vulgares y alejadas del vestuaro ordinario como son los pantalones de los buscadores de oro americanos, las casacas de aviador, las camisas de leñador, las botas de los militares, los monos de trabajo, las prendas deportivas, etc., por no hablar del reciclaje llevado a cabo por el movimiento punk o los raperos. Y no sólo eso, sino que además han logrado en algún caso hacerlas apetecibles al resto de edades y hacerlas pasar a formar parte de los circuitos de la moda popular. Esta estética se opone frontal y espontáneamente al gusto culto o distinguido, bien sea éste el clásico de los adultos de Pasapoga o el divulgado por la alta costura.

La composición estética de los chicos era también muy sencilla y bastante parecida a la de las chicas. Constaba de camisa o camiseta clara con motivos diversos en la parte delantera (relativos a la marca, deportiva - Nike, Reebok, NB, Adidas, etc. - o no, y mensajes o composiciones varias), jeans con pierna más estrecha, cinturón, pelo largo y zapatos, pues las zapatillas estaban prohibidas. Podía añadirse a todo ello algún pendiente, la ostentación del reloj y

22 No obstante, los significados que connotan los jeans son muchos más. Véanse al respecto los análisis de Fiske (1989: 1-21) y sus conclusiones para comprender la compleja lógica de la cultura popular. 
poco más. Pero de este uniforme es, sin duda, el esmeradamente cortado y peinado cabello largo el que más singularizaba a estos chicos de otros. Se trata de un corte más usual entre las mujeres pero que por esa época comenzó a divulgarse entre los varones jóvenes y que todavía hoy se exhibe. Era objeto de una preocupación similar a la de las mujeres, pues daba lugar a improvisados y espontáneos cuidados públicos e incluso a visitas al servicio para controlarlo mejor. $\mathrm{Su}$ antecedente entre los varones hay que buscarlo en el cabello largo comenzado a divulgar en los sesenta y mantenido por heavies y rockeros en general hasta hoy, pero su aspecto es mucho más cuidado. En cuanto a las camisetas, estamos también ante una prenda que, como sucediera antaño con la camisa, ha dejado de formar parte del vestuario íntimo y ha pasado a atraer las miradas. En efecto, hoy las camisetas, pero también las «chupas» de los heavies y las gorras de los raperos, son uno más de los soportes exhibidores de marcas, proclamas políticas o contraculturales, graffittis o firmas y composiciones pictóricas que van desde el realismo a los estilos cubistas y postmodernos. Se trata, sin duda, de la prenda que, junto al pantalón y las zapatillas deportivas (terminantemente prohibidas en But), más singulariza a los actuales jóvenes y que sirve de soporte para diferenciar según sus motivos o marcas a unas tribus de otras y a los mismos sujetos entre sí.

Descritas las composiciones vestimentarias de jóvenes y adultos, de lo que se trata es de averiguar cuáles son exactamente las sustancias significantes afectadas por la disidencia sociocultural juvenil. Por lo que respecta a los ideales estéticos de los adultos de Pasapoga, su función parece ser la de permitir el encuentro de mujeres bellas con varones de alta extracción social. Esto encaja perfectamente en el tipo de sociedad instituida por la modernidad por cuanto se adecúa a las nuevas estrategias conyugales que garantizan su reproducción. Por contra, los jóvenes se diferencian de los adultos en que prefieren la diferenciación tribal a la del estatus; pero, además, deben llevar a cabo un trabajo estético de considerable esfuerzo como es el mantener el dimorfismo de edad instituido por sus antecesores décadas atrás y desde entonces constantemente amenazado por la imitación que de su vestuario efectúan los adultos. Pero veamos el contraste más detenidamente

La estética de los adultos varones de Pasapoga es una metáfora de la ideología de la movilidad social por cuanto simboliza la lucha por la jerarquía en la escala de los estatus ${ }^{23}$. Esa metáfora se convirtió en hegemónica con la sustitución del sistema estamental distribuidor de privilegios por el meritocrático sistema de clases y la paulatina abolición de las leyes que, con sus prescripciones y proscripciones, imponían el vestuario y la ornamentación que correspondía a cada estamento (Deslandres, 1987: 196-200; Luján, 1996: 60-62). Desde entonces, puesto que no hay signos de distinción instituidos por ley, las clases altas se han visto obligadas a inventárselos para procurar distanciarse perma-

${ }_{23}$ Respecto a la función ostentosa y diferenciadora, véanse Veblen (1987: 160-179), Simmel (1923: 44-66) y Bourdieu (1991: 231 y ss.). 
nentemente de las bajas y éstas a imitarlos o a apropiárselos para emularlas. Se puede decir entonces que el derecho a la igualdad formal y la ideología meritocrática inaugurados por la Revolución Francesa, junto con el mantenimiento de una falta de movilidad social real, va a permitir la aparición de esta movilidad social simbólica que a la larga será uno de los más sólidos pilares sobre los que se asentará la reproducción de la estructura social. Por su parte, las mujeres de Pasapoga hemos visto que tienden a encarnar un ideal de belleza que tiene por misión el lograr atraer a los varones. Pues bien, esto también tiene su sentido en el contexto de la sociedad moderna. En general, la moda interesada en relacionar a los géneros resulta funcional para la reproducción demográfica de las sociedades y sus cambios vienen dados por la definición del encuentro que exija el entorno económico y social (Deslandres, 1987: 276-285). La moda masculina, que se inicia en 1350 y llega hasta 1750 (Gil Calvo, 1991: 45-57), coincide con el progresivo asentamiento de la familia de tipo troncal y el abandono de la medieval de linaje abierto. En este período los varones abandonarán progresivamente la cultura de la guerra, por lo que dejarán de competir violentamente entre ellos, y se asentarán en la sociedad cortesana, en la que la competencia se efectuará estéticamente y tendrá por objetivo la conquista de las mujeres para dar continuidad a las haciendas. Pero a esta moda masculina sucederá desde mediados del siglo XVIII otra protagonizada por las mujeres que se desenvuelve en un contexto económico y social distinto. Con el advenimiento de la sociedad industrial toma más importancia que la hacienda el empleo y, con él, la cualificación de los aspirantes a ocuparse, que a su vez dependerá del nivel de instrucción. Esto hará que sean los varones los que por sí mismos puedan independizarse de la familia de origen, y que serán entonces las mujeres las que deban articular estrategias hipergámicas que pasen por el estatus adquirido del varón para lograr emanciparse de la familia de origen. Así, pues, en la sociedad industrial, con la obligada instrucción, serán los hombres los escasos y por ellos deberán competir estéticamente las mujeres.

Por su parte, los jóvenes parecen conceder a su vestuario y estética otras utilidades: la diferenciación de los adultos, y la diferenciación de otras tribus juveniles. En relación al dimorfismo de edad hay que tener en cuenta que los jóvenes no comienzan a tener un aspecto estético y vestuario propio hasta este siglo, que es precisamente el de su aparición como clase de edad (Yonnet, 1988: 268 y ss.) $)^{24}$. Primero, en los años cuarenta, con la moda zazou; después, con el rock and roll, aparecerá una nueva estética de acusado dimorfismo sexual; más tarde, los hippies practicarán la antimoda y desde entonces las tribus juveniles inventan y divulgan modas distintas cada vez más rápidamente. Así, pues, si hasta mediados de este siglo es el vestuario adulto el que se impone a los jóvenes, desde entonces a la singularización estética como clase de edad específica acompañará la divulgación por la sociedad de un ideal estético

${ }^{24}$ En realidad, ni siquiera la infancia ha tenido vestuario propio hasta finales del siglo pasado (Deslandres, 1987: 189-196; Ariés, 1987: 79-84). 
juvenalizado y pasarán a ser los adultos los que imiten a los jóvenes. Es por esto que el mantenimiento de su singularidad ha exigido un esfuerzo de invención e innovación permanente que se ha incrementado mas aún con la aparición de las competencias estéticas entre tribus. En esa red de tribus lo que vale no es la adecuación a determinaciones estéticas trascendentales, sino a invenciones de look originales que, desatando competencias y hostilidades horizontales en las que ningún poder está dado de antemano, permiten que las tribus se diferencien entre sí. En opinión de Baudrillard (1991: 29-30), el look apunta a un «acto de diferencia» puro, ajeno a las lógicas de la distinción o de la seducción. Pero, además, los jóvenes de But se diferencian de los adultos de Pasapoga en algo que hemos descubierto con la genealogía de algunas de sus prendas, y que entronca con una de las señas de identidad de la cultura popular, el trabajo de apropiación efectuado de prendas provinientes de uniformes y vestuarios diferentes. Este bricolage que efectúan hoy los jóvenes dotando de sentidos nuevos a prendas originarias de otros ámbitos y el que en su momento efectuaron los que incorporaron el pantalón, la camisa, la corbata, etc., al uniforme de los adultos tienen en común un mismo distanciamiento perverso de los usos conversos instituidos y una misma capacidad para producir prendas al mínimo coste. En cambio, la alta costura, a la que no llegan ni la clase media ni los jóvenes, opera al revés. Es por esto que la clase de edad juvenil es hoy, respecto al asunto de la moda, la depositaria del genio popular.

\section{CONCLUSIÓN}

Después del análisis comparativo de los ceremoniales lúdicos del público juvenil de But y los de los adultos de Pasapoga ya se puede ofrecer una síntesis general del alcance de la disidencia sociocultural juvenil. Jóvenes y adultos tienden, por la inercia propia del divertimento, a alejarse del orden instituido en la sociedad y a generar sociabilidades distintas, en principio más afines a la socialidad. No obstante, entre el público adulto de Pasapoga, la enorme influencia de la sociedad, el respeto que se impone en el local de las normas y valores dominantes en el exterior y, lo más importante, su predisposición para someterse a ellos, hacen que, incluso divirtiéndose, la afinidad sea mucho más importante que la disidencia. En cambio, entre el público joven de But, a pesar de la influencia de la sociedad y de que la sala acepte sus normas y valores, comprobamos que la disidencia es más importante. Esto se debe a que no hay entre esta clase de edad tanta predisposición para la obediencia; o, mejor, que la jovialidad tiende a respetar mucho menos que la madurez el orden instituido. Así, pues, mientras los adultos tienden a contener la lógica disidente del divertimento, los jóvenes parecen incorporarse mucho mejor y más espontáneamente a ella, lo que da lugar a la deconstrucción de algunos pilares centrales de la sociedad moderna y, en algún caso, a la activación de otros alternativos.

Por lo observado en relación a los ceremoniales seleccionados, así como a 
los usos del espacio y los gustos musicales, las normas instituidas por la sociedad y aceptadas por Pasapoga y su público son las siguientes:

- En cuanto a la música, se apuesta por el ritmo y la melodía y quizás no tanto, como sucede en la música culta, por la armonía.

- Respecto a los usos del espacio, se respeta un estriaje basado en el principio de individuación, la asignación de lugares a cada sujeto, el mantenimiento de ciertas distancias y el predominio de la vista sobre otros sentidos, por lo que se puede decir que los adultos participan del estilo de vida sedentario, imprescindible en cualquier orden que pretenda ser estable y durar.

- Por lo que al agon interespecífico respecta, la obsesiva importancia concedida por los varones a la sexualidad y el juego de ocultación y ritualización a que es sometida en los ceremoniales de seducción indican que en la diversión adulta tiene una gran importancia el falocentrismo, así como la represión de la sexualidad, cuestión esta última también típicamente moderna.

- Respecto a las relaciones entre los sujetos, vimos que los adultos varones apuestan por la indiferencia más absoluta, así como por las relaciones conversacionales y los buenos modales, comportamientos todos ellos inscritos en la "curva civilizatoria» encargada de contener los instintos, en este caso el agresivo, tras la aparición del Estado y la monopolización estatal del uso de la violencia.

- En cuanto a la relación con los objetos, se ha visto que el buen trato que se les dispensa, así como el reconocimiento de su autonomía frente a los sujetos, son derivaciones de la mentalidad productivista tal como ha sido definida en la modernidad por el capitalismo.

- En el ilinx los análisis han demostrado que se respeta el yo impuesto por el racionalismo.

- Y en el mimicry se ha comprobado que, con su vestuario, varones y mujeres reproducen el meritocrático y falocéntrico sistema de clases que en la modernidad organiza gran parte de la desigualdad social.

En cuanto a los jóvenes de But, los análisis han demostrado que con sus ceremoniales lúdicos disienten significativamente del respeto que otorga la sociedad a los valores, ideologías, creencias y órdenes simbólicos anteriores:

- Frente a la melodía y los ritmos elaborados que tanto gustan a los adultos, los jóvenes apuestan casi exclusivamente por ritmos primarios con una cadencia muy similar en algunos casos a la de un corazón acelerado.

- En cuanto al espacio, las operaciones de alisamiento efectuadas sobre el estriaje impuesto por la sala, la importancia del principio de masividad y la relativización del sentido visual indican que estamos ante sujetos de espíritu nómada que disienten no sólo del sistema disciplinario, sino, en general, de cualquier orden instituido.

- Por lo que al agon interespecífico respecta, se ha comprobado que el 
falocentrismo (con su instinto de dominio y la asimetría de géneros) es fuertemente contestado, que la sexualidad no es objeto de tanta represión (por lo que desaparece el obsesivo interés por descargarla) y, como consecuencia de esto, que su manifestación se produce más espontáneamente, prácticamente sin ritual.

- En el agon intraespecífico observamos que el ritual aggro permite a los jóvenes tener experiencia de su agresividad y construir una paz social basada no en heterorregulación, sino en la autorregulación de la violencia.

- En relación a los objetos, los sujetos les otorgan valores de uso perversos que impiden su exteriorización y autonomía, así como valores sacrificiales que subrayan más todavía su posición de superioridad.

- En el ilinx el consumo de más potentes y variadas drogas permite huir del yo impuesto por la mentalidad racionalista y alcanzar otros estados subjetivos.

- Y en el mimicry la apuesta por vestuarios que refuerzan el dimorfismo de edad y la competencia tribal introduce al joven en una lógica social que nada tiene que ver con la de la distinción y seducción impuestas por la estructura social moderna.

En definitiva, mientras la actividad ritual adulta remite clara y nítidamente a ciertos pilares culturales básicos de nuestra sociedad (el estriaje de los espacios, la represión de la sexualidad, el tipo de paz social instaurada por el Estado, la mentalidad productiva, el racionalismo y la ideología meritocrática y falocéntrica del sistema de clases), de la de los jóvenes podemos decir que disiente de ellos pero, resulta imposible averiguar qué otros pilares culturales inspiran la acción.

No obstante, en algunos casos ha sido posible comprobar que el estilo de vida juvenil remite a sociabilidades que la modernidad necesitó suplantar para instituir su particular modo de organizar la sociedad. En efecto, los estados de conciencia no racionales (que después de preocupar a los teólogos interesaron a la medicina), las destructivas fiestas potlatch (recuérdese el enfrentamiento de los kwakiutl con las autoridades norteamericanas), el desorden dentro de ciertas organizaciones (como escuelas, cuarteles, hospitales, etc.) y la libertad de los instintos sexual y agresivo (magníficamente descrita por Elias) necesitaron ser abolidos o reconducidos por el orden social que se instituyó en la modernidad. El que esos flujos sociales retornen contemporáneamente a la superficie de la mano de los jóvenes —además, circulando más libre y voluptuosamente que antaño (pues entonces había ceremoniales, ritos y representaciones sociales más firmes que los contenían) — tiene que ver con la crisis del orden representativo moderno, que ya no permite mantenerlos sometidos por más tiempo, también con su enorme potencia, que impide a cualquier orden contenerlos indefinidamente y, sobre todo, con su permanente interés por asomarse (más o menos violenta y descarnadamente, dependiendo de lo duro y exigente que sea el orden). 
No sólo no se puede decir con claridad en qué consiste la alteridad juvenil, sino que también resulta difícil dar perfecta cuenta de las sustancias significantes a las que se adhiere. En efecto, las normas de la sociedad obligan a que esas potencias de la socialidad se vean forzadas a liberarse compulsivamente, o a dar un rodeo y manifestarse por otro lado, o a que se queden enredadas conflictivamente en la red de proscripciones y prescripciones que regulan la vida en la sociedad. A la postre, con lo que nos encontramos en casi todos los casos es con conductas reactivas.

En cualquier caso, parece que estos jóvenes de los noventa, parecen estar precipitando la crisis de algunos de los pilares centrales de la modernidad, ya que con ellos algunas buenas costumbres y ciertos valores están perdiendo la solidez que antaño tuvieron. Es como si el deseo de estos jóvenes no cargara, como el de los adultos, en el sistema de representaciones de la modernidad, sino en otros alternativos, más primarios y menos elaborados pero también más adecuados para contener su jovialidad. Es verdad que todos estos comportamientos disolutores del orden de la sociedad se daban ya entre los jóvenes de los sesenta, pero se diferencian de aquéllos en que la liberación de la sexualidad, la violencia, la ingestión de drogas, la antimoda, etc., se efectuaban entonces acudiendo a grandes discursos políticos, teóricos e ideológicos que pretendían ser la antítesis de los de la sociedad. Hacer el amor, consumir drogas, practicar la violencia y vestir jeans eran prácticas sociales justificadas con proyectos de revolución sexual, trascendentes experiencias místicas o espirituales, necesidades de cambiar ciertas estructuras sociales, y críticas de la moral y estética burguesas. Hoy todas esas prácticas, al tiempo que los grandes metarrelatos de legitimación y crítica políticos se han ido desmoronando, se ejecutan mucho más espontáneamente. Es por eso que la jovialidad se manifiesta hoy mucho más transparente y desfigurada que antaño. Y, por lo visto, aquí parece ser un exceso de vida y de deseo que espontánea e inercialmente tiende a disentir del orden instituido y a oponerse al exceso de civilización y de realidad de los adultos. Dicho de otro modo, en los términos sugeridos por García Calvo, el mundo en el que se actúa es en los jóvenes más importante que el mundo del que la sociedad instituida y el Estado hablan.

\section{BIBLIOGRAFÍA}

Agambern, G. (1995): Estancias. La palabra y el fantasma en la cultura occidental, Valencia: Pretextos.

Alaminos, A. (1994): «La cultura política de los jóvenes», en M. Martín Serrano (dir.), Historia de los cambios de mentalidades de los jóvenes entre 1960-1990, Madrid: Instituto de la Juventud.

AlCÁzar, M.; Trabada, E., y CAMACHO, J. (1993): «Grupos informales y apropiación del espacio urbano», en José C. Lisón Arcal (ed.), Espacio y cultura, Madrid: Coloquio.

Alvira, F. (1986): "Cambios en el consumo de bebidas alcohólicas en España», en REIS, 34, Madrid: CIS.

ARIÉS, P. (1987): El niño y la vida familiar en el Antiguo Régimen, Madrid: Taurus. 
BAJTIN, M. (1990): La cultura popular en la Edad Media y el Renacimiento, Madrid: Alianza.

BALANDier, G. (1975): Antropo-lógicas, Barcelona: Península.

- (1989): El desorden. La teoría del caos y las ciencias sociales, Barcelona: Gedisa.

BAtAille, G. (1987): La parte maldita, Barcelona: Icaria.

Bateson, G. (1991): Pasos hacia una ecología de la mente, Buenos Aires: Carlos Lohlé.

Baudelaire, Ch. (1961): Les paradis artificiels, París: Gallimard.

BAUdrILlard, J. (1988): El sistema de los objetos, México: Siglo XXI.

- (1991): La transparencia del mal, Barcelona: Anagrama.

BENVEniste, Émile (1969): Le vocabulaire des institutions indoeuropéens, 2, París: Seuil (2 vols.).

Bourdieu, P. (1991): La Distinción. Criterios y bases sociales del gusto, Madrid: Taurus.

- (1997): Razones prácticas, Barcelona: Anagrama.

Brown, N. O. (1986): El cuerpo del amor, Barcelona: Planeta-Agostini.

BÜHLER, K. (1985): Teoría del lenguaje, Madrid: Alianza.

CAILlois, R. (1967): Les jeux et les hommes. Les masques et le vertige, París: Gallimard.

CANETTI, E. (1982a): El poder y la masa, Madrid: Alianza.

- (1982b): La antorcha al oído, Barcelona: Seix Barral.

Certeau, M. de (1990): L'invention du quotidien, 1. Arts de faire, París: Gallimard.

- (1993): La culture au pluriel, París: Seuil.

Chesnais, C. (1981): Histoire de la violénce, París: Robert Laffont.

Cicourel, A. V. (1979): Sociologie cognitive, París: PUF.

- (1982): El método y la medida en sociología, Madrid: Editora Nacional.

Clastres, P. (1974): La société contre l'état, París: Minuit.

- (1981): Investigaciones en antropología política, Barcelona: Gedisa.

COMAS, D. (1985): El uso de las drogas en la juventud, Madrid: Instituto de la Juventud.

Deleuze, G., y Guattari, F. (1985): El Antiedipo. Esquizofrenia y capitalismo, Barcelona: Paidós.

- (1988): Mil Mesetas. Esquizofrenia y capitalismo, Valencia: Pre-textos.

- (1993): Qué es la filosofía, Barcelona: Anagrama.

DERRIDA, J. (1986): De la gramatología, Madrid: Siglo XXI.

DeSLANDRES, Y. (1987): El traje, imagen del hombre, Barcelona: Tusquets.

DODS, E. R. (1986): Los griegos y lo irracional, Madrid: Alianza.

DumaZidier, J. (1988): Révolution culturelle du temps libre (1968-1988), París: Meridiens Klinsieck.

DURAND, G. (1984): Les estructures antropologiques de l'imaginaire, París: Dunöd.

Duvignaud, J. (1990a): Herejía y subversión, Madrid: Icaria.

- (1990b): La solidaridad, México: FCE.

ELIAS, N. (1988): El proceso de civilización, Madrid: FCE.

Escohotado, A. (1989, 1990): Historia de las drogas (3 vols.), Madrid: Alianza,

EsPín MARTín, M. (1986): «La falsa imagen de los jóvenes en los medios de comunicación», en Revista de Estudios de Juventud (marzo), Madrid: Instituto de la Juventud.

FericGla, J. M. (1989): «El sistema dinámico de la cultura y los diversos estados de la mente humana», en Cuadernos de Antropología, 9, Barcelona: Anthropos.

FINK, E. (1966): Le jeu comme symbole du monde, París: Minuit.

FISKE, J. (1989): Understanding Popular Culture, Boston: Unwin Hyman.

FOESA, Fundación (1994): VInforme sobre la situación social de España (2 vol.), Madrid.

FOUCAULT, M. (1986): Vigilar y castigar, Madrid: Siglo XXI.

Freud, S. (1980): Tres ensayos sobre teoría sexual, Madrid: Alianza.

- (1982): «Metapsicología», en El malestar en la cultura, Madrid: Alianza.

- (1993): «Más allá del principio de placer», en Los textos fundamentales del psicoanálisis, Barcelona: Altaya.

Galland, O. (1991): Sociologie de la jeunesse, París: Armand Colin.

García Calvo, A. (1985): Razón común, Zamora: Lucina.

- (1989): Hablando de lo que habla, Zamora: Lucina. 
García Calvo, A. (1991a): Del lenguaje, Zamora: Lucina.

- (1991b): Noticias de Abajo, Zamora: Lucina.

- (1993): Contra el tiempo, Zamora: Lucina.

- (1995): «El hombre contra la gente» (conferencia pronunciada en la EU de Magisterio de Huesca).

GARRIDO, L. (1980): «Notas sobre adolescencia y sociedad», en Revista de Estudios de Juventud, 4, Madrid: Instituto de la Juventud.

GELLNER, E. (1994): Naciones y nacionalismos, Madrid: Alianza.

GIL CALvo, E. (1985): Los depredadores audiovisuales, Madrid: Tecnos.

- (1991): La mujer cuarteada, Barcelona: Anagrama.

Gil Calvo, E., y Meléndez Vergara, E. (1985): Ocio y prácticas culturales de los jóvenes, Madrid: Instituto de la Juventud.

GIRARD, R. (1983): La violencia y lo sagrado, Barcelona: Anagrama.

Grandi, R. (1995): Texto y contexto en los medios de comunicación, Barcelona: Bosch.

Grignon, C., y PASSeron, J.-C. (1992): Lo culto y lo popular, Ediciones La Piqueta.

HACKER, F. (1973): Agresión, Barcelona: Grijalbo.

HALL, E. T. (1987): La dimensión oculta, Madrid: Siglo XXI.

HaLl, S. (1992): "Cultural Studies and its Theoretical Legacies», en L. Grossberg, C. Nelson y P. Teacher (comps.), Cultural Studies, Londres: Routledge.

HARRE, R. (1987): "El gamberrismo en el fútbol», en Revista de Occidente (marzo), Madrid: Fundación Ortega y Gasset.

Heinze, R. G.; Hinrichs, K.; Offe, C., y OlK, T. (1992): «Diferenciación de intereses y unidad sindical", en Claus OfFe, La sociedad del trabajo. Problemas estructurales y perspectivas de futuro, Madrid: Alianza.

Huizinga, J. (1972): Homo ludens, Madrid: Alianza.

IbáñeZ, J. (1985): Del algoritmo al sujeto. Perspectivas de la investigación social, Madrid: Siglo XXI.

- (1994): Por una sociología de la vida cotidiana, Madrid: Siglo XXI.

IMBERT, G. (1992): Los escenarios de la violencia, Barcelona: Icaria.

InSTITUTO DE LA JUVENTUd (1991): Actitudes politicas de la juventud en España, Madrid: Instituto de la Juventud.

Irigaray, L. (1987): Sexes et parentés, París: Minuit.

- (1992): Yo, tú, nosotras, Madrid: Cátedra.

Jiménez, D. (1994): "Cáritas y los jóvenes», en Los jóvenes, Madrid: Cáritas (Documentación Social, 95).

KeEney, B. P. (1987): Estética del cambio, Buenos Aires: Paidós.

KRISTEVA, J. (1981): Semiótica, Madrid: Fundamentos (2 vols.).

Lamo de Espinosa, E. (1993): Delitos sin víctimas. Orden social y ambivalencia moral, Madrid: Alianza.

LÉVI-STRAuss, C. (1976): El hombre desnudo, Madrid: Siglo XXI.

LeVices Mallo, J. J., y Serrano PASCUAL, A. (1993): «Estructura social y estructura musical», en Revista Internacional de Sociología, 6, Madrid: Consejo Superior de Investigaciones Científicas.

LIPOVETSKI, G. (1987): La era del vacío, Barcelona: Anagrama.

LLES, L. (1994): "Cibersonidos. Del futurismo al trip hop», en Rock de Lux, 113, Barcelona.

- (1995): "Zang Tumb techno", en El Gran Musical, 414, Madrid.

LORENZ, K. (1972): Sobre la agresión. El pretendido mal, Madrid: Siglo XXI.

Lozano, J.; PeÑa Marín, C., y Abril, G. (1989): Análisis del discurso, Madrid: Cátedra.

LOZANO I Soler, J. (1994): «¿De qué hablamos cuando hablamos de los jóvenes?, en Los jóvenes, Madrid: Cáritas (Documentación Social, 95).

LYON, D. (1994): El ojo electrónico, Madrid: Alianza.

LUJÁN, N. (1996): La vida cotidiana en el siglo de oro español, Barcelona: Planeta-Agostini.

MAFFesoli, M. (1979): La conquete du présent, París: PUF.

- (1985): L'ombre de Dionysos. Contribution a une sociologie de l’orgie, París: Librairie des Meridiens. 
MAFFESOLI, M. (1990): El tiempo de las tribus, Barcelona: Icaria.

- (1992): La trasfiguration du politique, París: Grasset.

MaIral, G. (1995): Antropología de una ciudad. Barbastro, Zaragoza: Instituto Aragonés de Antropología.

Martín SAnTOS, L. (1988): Diez lecciones de sociología, Madrid: Fondo de Cultura Económica.

Martín SERrano, M. (1982): "Génesis de la comunicación" y "Análisis de la referencia», en Manuel Martín SERrano (y otros), Teoría de la comunicación. I. Epistemología y análisis de la referencia, Madrid: Alberto Corazón.

- (1991): Los valores actuales en la juventud en España, Madrid: Instituto de la Juventud.

MCLuhan, M. (1985): La galaxia Guttenberg, Madrid: Planeta-Agostini.

Modell, J. (1991): De la juventud a la edad adulta en Estados Unidos 1920-75, Madrid: Ministerio de Trabajo y Seguridad Social.

Muñoz CARrión, A. (1985): «El ceremonial comunicativo y la expulsión de la palabra», en Los Cuadernos del Norte, 29, Oviedo.

- (1988): «De la relación comunicativa a la comprensión de la palabra: elementos para una antropología de la comunicación», en Cuadernos de Realidades Sociales, 31-32, Madrid: Instituto de Sociología Aplicada.

- (1994a): «Lugares oscuros. Dificultades "emic" y "etic" en la aproximación a las discotecas", en José A. Younis (comp.), Cultura, psicología y problemas sociales, Las Palmas de Gran Canaria: Librería Nogal Ediciones, Excmo. Cabildo Insular de Gran Canaria, Universidad de Las Palmas de Gran Canaria.

- (1994b): "Consumo y ocio», en M. Martín Serrano (dir.), Historia de los cambios de mentalidades de los jóvenes entre 1960-1990, Madrid: Instituto de la Juventud.

Navarro, M., y Mateo, M. J. (1993): Informe juventud en España. Madrid: Instituto de la Juventud.

NúNEZ GARCíA, M. (1988): «Gasto (teoría del)», en Román Reyes (dir.), Terminología científicosocial. Aproximación crítica, Barcelona: Anthropos.

NietzSCHE, F. (1987): El nacimiento de la tragedia, Madrid: Alianza.

Oriol Romaní, A. (1989): "Proceso de modernización, cultura juvenil y drogas», en Félix RODRíguez GONZÁlez (ed.), Comunicación y lenguaje juvenil, Madrid: Fundamentos.

ORTEGA Y GASSET, J. (1994): La rebelión de las masas, Madrid: Espasa-Calpe.

Ortiz-OsÉs, A. (1993): Las claves simbólicas de nuestra cultura. Matriarcalismo, patriarcalismo y fratriarcalismo, Barcelona: Anthropos.

PASSERINI, L. (1996): "La juventud, metáfora del cambio social (dos debates sobre los jóvenes en la Italia fascista y en los Estados Unidos durante los años 50)", en G. Levi y J.-C. Schmitt (eds.), Historia de los jóvenes, 1. De la Edad Antigua a la Edad Moderna, Madrid: Taurus.

Piaget, J. (1986): La formación del símbolo en el niño, México: Fondo de Cultura Económica.

Prieto Lacaci, R. (1985): «La participación social y política de los jóvenes», en Revista de Estudios de Juventud, Madrid: Instituto de la Juventud.

- (1991): Asociacionismo juvenil en el medio urbano, Madrid: Instituto de la Juventud.

Reguillo, R. (1991): En la calle otra vez, México: Iteso.

Robles, R. (1993): «El día que murió el acid house», en Ajoblanco, 49, Barcelona.

RODRíGUEZ GONZÁlEZ, F. (1989): «Lenguaje y cultura juvenil: anatomía de una generación», en Félix Rodríguez GonzÁlez (ed.), Comunicación y lenguaje juvenil, Madrid: Fundamentos.

SÁnCheZ Ferlosio, R. (1992): "Juegos y deportes», en El País, 9/8/92, Madrid.

SAnidad y Consumo, Ministerio de (1995): Alcohol y juventud 1995, Madrid: Servicio de Publicaciones.

SÁEZ MARÍn, J. (1995): «Los estudios sobre juventud en España: Contextos de un proceso de Investigación-Acción (1960-1990)», en Revista Internacional de Sociología, 10, Madrid: CSIC.

SAID, E. W. (1990): Orientalismo, Madrid: Ediciones Libertarias.

SANTA MARÍA, Fundación (1984): Informe sociológico sobre la juventud española (1960-82), Madrid: Ediciones SM. 
SANSONE, L. (1988): "Tendencias en blanco y negro: punk y rastafarismo», en Revista de Estudios de Juventud, Madrid: Instituto de la Juventud.

Simmel, J. (1927): "Filosofía de la moda», en Revisa de Occidente, 1, Madrid: Calpe.

Skoff Torgue, H. (1977): Introducción a la música pop, Barcelona: Oikos Tau.

SZASZ, T. (1990): Droga y ritual, Madrid: Fondo de Cultura Económica.

Tinbergen, N. (1985): "Guerra y paz entre los animales», en varios autores, Hombre y animal, Barcelona: Orbis.

Toussaint-Samat, M. (1994): Historia técnica y moral del vestido, 3. Complementos y estrategias, Madrid: Alianza.

VARela, J., y Álvarez Uría, F. (1986): Las redes de la psicología, Madrid: Ediciones Libertarias.

VEBLEN, T. (1987): Teoría de la clase ociosa, Barcelona: Orbis.

VIOLI, P. (1991): El infinito singular, Madrid: Cátedra.

WinnicotT, D. W. (1993): Realidad y juego, Barcelona: Gedisa.

YONNET, P. (1988): Juegos, Modas y Masas, Barcelona: Gedisa.

ZÁrragA, J. L. de (dir. y red.) (1985): Informe juventud en España, Madrid: Instituto de la Juventud.

- (1986): Informe juventud en España. Tablas estadísticas del programa de investigaciones básicas sobre la juventud, Madrid: Instituto de la Juventud.

\begin{abstract}
Youth should not be defined by its shortcomings with respect to adulthood, derived from the subordinate status it occupies in society's central institutions such as work and family. On the other hand, it is necessary to identify the cultural difference between youth and adulthood, paying particular attention to the singular forms of social behaviour in which today's youth indulges. On the basis of this notion and following in the footsteps of Caillois, this paper compares the agon (interpersonal relations among sexes and with objects), ilynx (self-alteration of the conscious self through drug-taking) and mimicry (symbolic uses and functions ascribed to clothes) ceremonials, in addition to the appropriation of space and musical tastes, and the young and adult patrons of Madrid's But discothèque and Pasapoga nightclub. The conclusion is that whereas adults allow certain emblematic sociocultural pillars of modernity, young people - through inertia and spontaneously — tend to erode their dominion.
\end{abstract}


NOTAS DE INVESTIGACIÓN 